\title{
Understanding the technology of computer technology diffusion: explaining computer adoption patterns and implications for the wage structure
}

Citation for published version (APA):

Borghans, L., \& ter Weel, B. J. (2008). Understanding the technology of computer technology diffusion: explaining computer adoption patterns and implications for the wage structure. Researchcentrum voor Onderwijs en Arbeidsmarkt, Faculteit der Economische Wetenschappen. ROA Research Memoranda No. 008 https://doi.org/10.26481/umaror.2008008

Document status and date:

Published: 01/01/2008

DOI:

10.26481/umaror.2008008

Document Version:

Publisher's PDF, also known as Version of record

Please check the document version of this publication:

- A submitted manuscript is the version of the article upon submission and before peer-review. There can be important differences between the submitted version and the official published version of record.

People interested in the research are advised to contact the author for the final version of the publication, or visit the DOI to the publisher's website.

- The final author version and the galley proof are versions of the publication after peer review.

- The final published version features the final layout of the paper including the volume, issue and page numbers.

Link to publication

\footnotetext{
General rights rights.

- You may freely distribute the URL identifying the publication in the public portal. please follow below link for the End User Agreement:

www.umlib.nl/taverne-license

Take down policy

If you believe that this document breaches copyright please contact us at:

repository@maastrichtuniversity.nl

providing details and we will investigate your claim.
}

Copyright and moral rights for the publications made accessible in the public portal are retained by the authors and/or other copyright owners and it is a condition of accessing publications that users recognise and abide by the legal requirements associated with these

- Users may download and print one copy of any publication from the public portal for the purpose of private study or research.

- You may not further distribute the material or use it for any profit-making activity or commercial gain

If the publication is distributed under the terms of Article $25 \mathrm{fa}$ of the Dutch Copyright Act, indicated by the "Taverne" license above, 


\section{Understanding the Technology of Computer Technology Diffusion: Explaining Computer Adoption Patterns and Implications for the Wage Structure}

Lex Borghans

Bas ter Weel

ROA-RM-2008/8

October 08

Research Centre for Education

and the Labour Market

P.O. Box 616

6200 MD Maastricht

The Netherlands

E-mail: $\quad$ secretary@roa.unimaas.nl

Internet: $\quad$ www.roa.unimaas.nl

Maastricht University

Faculty of Economics and Business Administration 
The ROA Research Memorandum Series was created in order to make research results available for discussion, before those results are submitted for publication in journals.

Sec08.153.pdf 
ROA-RM-2008/8 » http://www.roa.unimaas.nl/resmem.htm

\section{Abstract}

\section{Understanding the Technology of Computer Technology Diffusion: Explaining Computer Adoption Patterns and Implications for the Wage Structure ${ }^{1}$}

We review the empirical literature about the implications of the computerization of the labor market to see whether it can explain observed computer adoption patterns and (long-term) changes in the wage structure. Evidence from empirical micro studies turns out to be inconsistent with macro studies that are based on CES production functions. We propose a micro foundation for the CES production function that allows for changes in the underlying structure. We adapt the macro model by incorporating computer skills, complementary skills and fixed costs for computer technology usage suggested by the micro literature. It turns out that fixed costs for computer technology usage explain different patterns of computer adoption and diffusion between several types of workers and countries; it also provides very plausible patterns of the timing of wage inequality and developments over time.

JEL codes: J31, O15, O33

Keywords: wage level of structure, computer technology, technology diffusion

1. The authors would like to thank Stefan Boeters, Arnaud Dupuy, Albert van der Horst, Michael Sattinger and participants at the $9^{\text {th }}$ ZEW Summer Workshop in Mannheim for useful comments on an earlier version of this paper. 
Lex Borghans

Maastricht University

Department of Economics and ROA

P.O. Box 616

NL-6200 MD Maastricht

The Netherlands

lex.borghans@algec.unimaas.nl
Bas ter Weel

CPB Netherlands Bureau for Economic

Policy Analysis and Department of Economics and UNU-MERIT, Maastricht University

P.O. Box 616

NL-6200 MD Maastricht

The Netherlands

b.ter.weel@cpb.nl 


\section{Introduction}

Over the last four decades or so the world has experienced an enormous increase in the use of computer technology at work. The adoption and diffusion of computers started with only a few workers applying computer technology in the 1970s; currently the vast majority of workers in developed countries uses some kind of computer technology ${ }^{1}$ The patterns of computer technology diffusion have not been the same across countries and have been dissimilar for various types of workers both within and between occupations. These differences in computer technology adoption and diffusion have led to the fear of increased inequality within and between countries and within and between categories of different worker types. At the national level, people feared a "digital divide" between users and non-users, which translates into increasing levels of wage inequality between those who use computer technology and those who do not. ${ }^{2}$ Similarly, at the international level, countries lagging behind in terms of computer technology adoption feared a loss of competitiveness and were afraid of falling behind (i.e., a "global digital divide"). Analyses by economists both at the micro and macro level seem to partially support this fear for the appearance of a "digital divide". Comparison of these literatures puts forward an interesting distinction, though. The macro literature predicts increased wage inequality between different groups of workers because computer technology complements the input of one group and substitutes for the input of the other. Studies using micro data show that computer technology is used by all types of workers, but that conditional on observables, specific computer users within different categories fare much better in the labor market.

How can we reconcile these apparently different approaches and outcomes analyzing the same technological development? The issue at stake is twofold. How can we improve the understanding of what happens with individual workers taking into account findings from the macro literature? How can we improve our knowledge of the macro developments by taking into account what we know from the micro literature about individual workers? The theoretical approach we follow is to account for worker

\footnotetext{
${ }^{1}$ Bresnahan and Greenstein (1996), Bresnahan (1999) and ter Weel (2006) provide overviews of the development of computer technology applications and their use in the workplace.

${ }^{2}$ President of the United States Bill Clinton addressed this fear in a 1996 speech in Knoxville, Tennessee. His specific fear at that time was the divide between those who could afford to buy an Internet connection and those who could not.
} 
heterogeneity within groups to enrich the standard macro approach and to explicitly model the decision of computer technology adoption at the individual level to understand what happens at the micro level. To do so, we build on two seminal contributions in the field of technology diffusion, because the development of the adoption and diffusion of computer technology in recent decades resembles striking similarities with the diffusion of many other technologies described and studied earlier.

First, Zvi Griliches' work on the diffusion of the usage of hybrid seed to produce corn by farmers in five U.S. states from the 1930s onwards is the classical example of technology diffusion (Griliches, 1957). Figure 1 shows the diffusion pattern of the use of hybrid seed he documented in these states. The picture shows the percentage of total corn acreage planted with hybrid seed in five U.S. states. Two observations stand out from this picture. First, farmers in each of these five U.S. states did not take the opportunity of adopting hybrid seed at the same time. Farmers in Iowa adopted the seed first and those in Alabama last, with the first farmers in Alabama adopting earlier than the last ones in Iowa. Second, the rate of diffusion differs across states; almost all farmers in Iowa used hybrid seed ten years after its introduction, while among Texan farmers the diffusion rate was around 70 percent ten years after its first usage. Griliches' contribution started a literature trying to explain technology diffusion patterns. Farmer abilities, company size and the dynamics of how news about new technologies spreads are the main ingredients of these theories ${ }^{3}$ The basic line of thought is that new technology is superior to the old one and that the period of time in which the diffusion takes place is an out of equilibrium situation in which productivity is below its potential level. Analyses based on CES production functions with the stock of the new equipment as one of the inputs seem to support this view.

The second seminal contribution is a working paper by Paul A. David. David (1969) develops a theory in which the optimal decision to adopt new technology differs between farmers because of heterogeneity in one (or more) relevant dimension(s). In the case of farmers the most prominent dimension is farm size. Suppose that the use of hybrid seed requires a fixed partially size independent investment, while the returns are mainly relative to the size of the harvest. For farms of different sizes a cost-benefit

\footnotetext{
${ }^{3}$ Geroski (2000) provides an overview of the several models of technology diffusion.
} 
calculation might lead to different decisions about the use of hybrid seed. With costs and returns of the use of the seed changing over time, the decision threshold shifts. David shows that the within-state diffusion pattern of hybrid seed is a reflection of the cumulative density function of firm size. Farmers below the threshold would not benefit from using hybrid seed because production (e.g., the absolute number of crops) is too low. Between-state differences reflect differences in the cumulative density functions. Conditional on the distribution of firm size, this process generates between-farm income differences but does not reflect inefficiencies. As the further diffusion brings in smaller and therefore less productive farms, the aggregate effects might resemble the patterns predicted by a CES production function, but the long-run consequences will be very different.

Turning back to computer technology diffusion, Figure 2 provides information about computer technology diffusion in the United States, Germany and Britain. The numbers mainly refer to the use at work of personal(ized) computer technologies. The diffusion patterns follow a more or less similar pattern as those documented by Griliches (1957) for the diffusion of hybrid seed (Figure 1). Interestingly, the diffusion of computer technology is slower than the diffusion of hybrid seed. In addition, while U.S. workers had the lead in computer use at work in the 1980s, EU workers overtook them in the 1990s. Between the mid-1980s and the late-1990s the use of personal computers in the workplace increase from 19.3 to 69.2 percent in Britain, from 19.3 to 56.2 percent in Germany and from 24.3 to 52.5 percent in the United States. In 2001, computer technology use at work in Britain reached 71 percent and 67 percent in the United States.

These differences have been interpreted as a sign that Europe was operating below its technology frontier, and raised worries about the international position of countries comparable to the discussions about the digital divide within countries. The question is whether Europe was slow in adopting computer technology in the workplace due to a lack of innovativeness or that there was an underlying factor that accounted for differences in computer technology adoption over time.

In this paper we review the macro and micro literature about the adoption of computers. We will extend the standard macro CES model to analyze individual behavior within the same framework from the angle of the decision to adopt computer technology 
in the workplace. Rather than farm size, individual productivity is regarded to be heterogeneous among workers. This might explain why within skill or age groups workers differ in their adoption of computer technology and why different groups have a different timing of computer technology adoption.

This paper proceeds as follows. Section 2 presents the approach to documenting and explaining wage inequality at the macro level. Section 3 does the same for analysis at the micro level. Section 4 presents our unifying framework to bring these two literatures together. By means of a set of simulation results we show how these seemingly different worlds fit together. Section 5 interprets our findings and concludes.

\section{Computer technology at work: macro level}

The adoption of computer technology has coincided with relatively large changes in the wage structure in many OECD countries. These trends have been carefully documented for the United States by Katz and Murphy (1992), Katz and Autor (1999) and Acemoglu (20022. ${ }^{4}$ These authors divide the labor market into skilled and unskilled workers. Basically college graduates are defined as skilled workers and high school graduates and below are unskilled worker. 5

Figure 3 presents the actual (1963-2002) and predicted (1963-2010) development of the wage differential between skilled and unskilled workers in the United States using the March supplements to the Current Population Surveys (CPS). The actual development shows the development of relative wages for full-time full-year workers. The picture reveals a steady increase in relative wages since the early 1980s, which coincides with the first introduction and diffusion afterwards of computer technology at work. It is this development from 1980 onwards of the relative wage between skilled and unskilled workers that has led many to conclude that we are facing a digital divide.

The predictions of the wage development stem from a prototype CES analysis in which output is a function of skilled and unskilled labor:

$$
Y=\alpha\left(\left(\gamma_{S} S\right)^{\rho}+\left(\gamma_{U} U\right)^{\rho}\right)^{1 / \rho} .
$$

\footnotetext{
${ }^{4}$ Freeman and Katz (1995), Gottschalk and Smeeding (1997), Berman, Bound and Machin (1998), Gottschalk and Joyce (1998), Machin and Van Reenen (1998), Hollanders and ter Weel (2002) and Acemoglu (2003) present changes in the wage structure for other OECD countries as well.

${ }^{5}$ The data are taken from the CPS March supplements.
} 
In this equation $\alpha$ is a scale parameter, $\gamma_{S}$ and $\gamma_{U}$ reflect the productivity of skilled and unskilled workers, $S$ and $U$ reflect the supply of skilled and unskilled labor, and $\rho$ is a substitution parameter. The elasticity of substitution between skilled and unskilled labor is defined as $\sigma=1 /(1-\rho)$. Equalizing the wages $(w)$ of skilled and unskilled workers to their marginal productivity gives an equation for relative wages:

$$
\frac{w_{S}}{w_{U}}=\left(\frac{\gamma_{S}}{\gamma_{U}}\right)^{\rho}\left(\frac{S}{U}\right)^{\rho-1}
$$

Taking logs yields

$$
\ln \left(\frac{w_{S}}{w_{U}}\right)=\rho \ln \left(\frac{\gamma_{S}}{\gamma_{U}}\right)+(\rho-1) \ln \left(\frac{S}{U}\right)=\rho \ln \left(\frac{\gamma_{S}}{\gamma_{U}}\right)-\frac{1}{\sigma} \ln \left(\frac{S}{U}\right) .
$$

A gradual rise in the productivity of skilled workers in this framework can be represented by adding a (linear) time trend to the productivity parameter of this skill group: $\gamma_{S} t^{\beta}$. This results in the following equation for estimation:

$$
\ln \left(\frac{w_{S}}{w_{U}}\right)=\rho \ln \left(\frac{\gamma_{S}}{\gamma_{U}}\right)-\frac{1}{\sigma} \ln \left(\frac{S}{U}\right)+\beta t .
$$

Based on the relative wages of skilled and unskilled workers and their relative supplies this linear relationship can simply be estimated with ordinary least squares (OLS).

Table 1 provides the results for the period 1963-2002. The first column replicates the results from Katz and Murphy (1992) for the period 1963-1987 and the third column displays the estimates until 2002. The estimates presented in columns (2) and (4) of Table 1 include an extra time trend from 1980 onwards. The results reveal a significant annual relative increase of the productivity of skilled workers of between 1.9 and 2.5 percent and an elasticity of substitution ranging from 1.4 to 1.7 . The positive time trend in the productivity of skilled workers is generally interpreted as the effect of skill-biased technological change and related to the diffusion of computers or other skill-enhancing technological developments (see Acemoglu (2002) for an overview). Since 1980 is often regarded as the year in which the computerization of the workplace started (although in the seventies mainframe computer use was already substantial) a trend break in 1980 is 
introduced in the analysis ${ }^{6}$ Column (2) in Table 1 shows that this leads to a more modest relative wage growth for skilled workers before 1980; qualitatively it does not alter the picture. For the period 1963-2002 the skill-biased technological change effect does not change if an additional time trend is added.

Figure 3 also provides predictions until 2010 of the further development in wage inequality if the development in the relative supply and wages of skilled and unskilled workers in the United States would continue at the same pace as in the 1980s and 1990s. The series are extended using model estimates based on information from the KatzMurphy period (1963-1987) and the period from 1963 until 2002 as points for departure. As the picture reveals, a linear continuation of the trends would indeed be a serious threat for unskilled workers, especially when predicting from the Katz-Murphy trend onwards. However, since the early 1990s the increase in relative wages for skilled workers leveled off and wage inequality did not rise substantially since that time, which is revealed by a much lower prediction when the series are extended from 2000 onwards. Dupuy and Marey (2008) and Dupuy (2008) note that the estimated elasticity of substitution shifts when time progresses, while in the simple CES models estimated here it is estimated as a constant parameter over time. Indeed, Autor, Levy and Murnane (2003), and Autor, Katz and Kearney (2006 and 2008) report more subtle changes in the wage composition, decreasing wages for workers in (what they refer to as) routine jobs, and increasing wages for workers in non-routine skilled and unskilled jobs. They also find rising wages at the very bottom, suggesting a trend towards polarization of work in which demand for jobs in the middle of the wage distribution is falling the most. ${ }^{7}$ So, fears fed by the labormarket developments of the early 1990s and projections of (linear) trends by a number of naive analysts and economists suggesting ever increasing between-group wage inequality never became reality.

In this framework, the effect of the diffusion of computer technology on productivity is introduced by way of a simple time trend in the productivity of skilled workers. One could regard this as unsatisfactory as the pace of technological progress

\footnotetext{
${ }^{6}$ Greenwood and Yorukoglu (1997) argue that 1974 is the watershed, because computer technology becomes significantly cheaper after that time.

${ }^{7}$ See also Autor and Dorn (2008) for an analysis of the emergence of a low-skilled service economy in the United States.
} 
might differ between different years. A more elegant way to model computer technology diffusion is to incorporate it as a third factor of production. Krusell et al. (2000) introduce such an approach in a nested CES production function with skilled and unskilled labor and computer equipment as inputs. ${ }^{8}$

A nested production function provides a number of possibilities to include computer technology as an input. The first option is to assume that skilled labor $(S)$ and computer technology $(C)$ are inputs for an intermediate product $\left(Y_{S}\right)$ :

(5a) $\quad Y_{S}=\alpha_{S}\left(\left(\gamma_{S} S\right)^{\rho}+\left(\gamma_{C} C\right)^{\rho}\right)^{1 / \rho}$.

Together with unskilled labor this leads to final output

$$
Y=\alpha\left(\left(\gamma_{Y} Y_{s}\right)^{\delta}+\left(\gamma_{U} U\right)^{\delta}\right)^{1 / \delta}
$$

The other option is that computer technology and unskilled labor together produce an intermediate product $\left(Y_{U}\right)$, i.e.

$$
\text { (6a) } \quad Y_{U}=\alpha_{U}\left(\left(\gamma_{U} U\right)^{\rho}+\left(\gamma_{C} C\right)^{\rho}\right)^{1 / \rho} \text {. }
$$

Combined with skilled labor this leads to final output

(6b) $\quad Y=\alpha\left(\left(\gamma_{S} S\right)^{\delta}+\left(\gamma_{Y} Y_{U}\right)^{\delta}\right)^{1 / \delta}$.

To obtain the result that in increase in the use of computer technology leads to an increase in relative wages, computer technology has to be a relative complement to skilled labor in the first case (equations 5) and a relative substitute to unskilled labor in the second case (equations 6).

To get to grips with both ways of modeling the effects of computer technology on relative wages, consider an example of a manager and his secretary. The story consistent with equations (5) is one in which computers make the manager more productive, while they do not affect (or less so) the productivity of the secretary. The second case is one in which computers do not affect the productivity of the manager but take over part of the work of the secretary (i.e., equations 6). From traditional analyses using aggregate data it is hard to judge which interpretation is more accurate. Krusell et al. (2000) choose the

\footnotetext{
${ }^{8}$ Krusell et al. (2000) also incorporate traditional capital as an input into their model, but since this is not relevant for relative wages we abstract from this. See Acemoglu (2002) for a critical assessment of the results obtained by Krusell et al. (2000).
} 
first interpretation because of a slightly better fit of this specification.?

Estimates for the period 1963-1987, as first presented by Katz and Murphy (1992), and forecasts for the later years provide similar results. The reason for this is that the diffusion of computer technology in the labor market has been a very gradual process. When applying this model a choice can be made of either using the stock of computer technology equipment or the price of computer equipment - assuming optimal investments given these prices. Both series turn out to be very close to following a linear trend, hence providing almost identical results as in the initial Katz-Murphy study ${ }^{10}$

Our contribution in this paper is not to come up with better predictions compared to previous studies, but with a way to think about how computer technology has been changing the jobs of both skilled and unskilled workers. The current literature makes a choice between equations (5) and (6) to model the effects of computer technology diffusion on relative wages, but it is more appropriate to present a model in which the diffusion of computer technology changes the (content of) work of skilled and unskilled workers at the same time. In terms of Figure 2 this translates into different labor-market groups adopting the technology at different points in time and at different paces, just like farmers in different U.S. states did. The micro evidence we turn to in the next section indeed supports the idea that computer technology is gradually adopted by different types of workers at different paces.

In addition, we need to answer a number of questions, because the macro approach based on CES production functions leaves several issues open. The main unanswered question is what caused the sharp increase in relative wages in the United States to level off since the mid-1990s (see Figure 3). Another interesting question is why the United States had the lead in computer technology adoption, but European countries overtook the country in the 1990s (see Figure 2). In addition, wage inequality among skilled workers started to increase in the 1970s in the United States, while wage inequality within the group of unskilled workers only started to increase around 1980.

\footnotetext{
${ }^{9}$ Borghans and ter Weel (2004) and (2006) provide a model in which they explain the consequences of both ways of approaching the effects of computer technology on the organization of work and wages.

${ }^{10}$ See also Acemoglu (2002) for a discussion of the Katz-Murphy and Krusell et al. results. Greenwood and Yorukoglu (1997) and Jorgenson (2001) provide these series for the costs of computer equipment. Autor, Katz and Krueger (1998) and Borghans and ter Weel (2007) compute the costs of computer technology usage for individual workers using these series.
} 
Why? These questions are not easily answered by the standard macro approach using a CES production function with two inputs and need a richer model. Section 4 presents such a model, but first we need to assess and interpret the findings from the micro literature to learn more about computer technology adopters.

\section{Computer technology at work: micro level}

Table 2 summarizes the incidence of computer technology use for different categories of workers in Britain, Germany and the United States in the mid-1980s and late 1990s ${ }^{11}$ Computer technology use in the mid-1980s is lower in Germany and Britain than in the United States, but the levels of computer use in Germany and Britain are higher by 1997. Differences in these figures might of course be the result of different wordings of the questions in the survey, but comparisons with other sources of information about computer technology usage suggest that such effects are likely to be of a small magnitude..$^{12}$

The prominent message from the table is that although computer technology use at work is increasing over time, the patterns of use among various labor-market groups are very similar in relative terms. Computers are predominantly used by the higher educated, but there is also a considerable group of lower educated workers whose jobs involve the use of computer technology. This is in contrast with the assumptions of the macro models, which suggest that the technology is either used by skilled or by unskilled workers.

In contrast to what is often expected, the highest rate of computer technology use at work is not found in the youngest age group (20-29): workers in the age group 30-39 or 40-49 are the most frequent users of computer technology and the oldest group of workers does not seem to suffer to a large extent from the adoption and diffusion of

\footnotetext{
${ }^{11}$ Others have documented patterns of computer technology for different countries. Borghans and ter Weel (2005) provide an overview of these studies.

${ }^{12}$ Another problem with this information is that the use of computer technology is measured by the direct use of (personal) computers by workers. While this measure is incomplete and misses workers who use devices with embedded microprocessors, we believe that it does reflect a particularly prevalent form of computer technology that has been important in both the production process and in facilitating modern forms of communication in the workplace.
} 
computer technology. ${ }^{13}$ What is also interesting to observe is that women are generally more likely to use computer technology at work than men, especially in the United State ${ }^{14}$ This suggests that it is not in the first place the ability to operate a computer that determines diffusion.

Krueger (1993) was the first to estimate the relationship between computer use at work and wages. He augmented a standard cross-sectional earnings function by including a dummy variable indicating whether or not individual $i$ uses a computer at work:

$$
\ln W_{i}=\alpha+\beta_{i} X_{i}+\gamma_{i} C_{i}+\varepsilon_{i},
$$

where $C_{i}$ represents a dummy variable that equals 1 if individual $i$ uses computer technology at work, and 0 otherwise, $\ln W_{i}$ is the $\log$ of the hourly wage of worker $i ; X_{i}$ represents a vector of observed characteristics; and $\alpha$ is the intercept.

Table 3 reports the coefficients of estimating equation (7) for the United States using the October Supplements to the 1984, 1989, 1993 and 1997 Current Population Surveys. Inclusion of several covariates to the wage equation suggests that computer users earn substantially higher wages than non-users and that the coefficient is relatively stable over time, ranging from 15.5 (exp(.144)-1) to $21.3(\exp (.153)-1)$ percent. Inclusion of only a dummy variable for using a computer at work leads to wage differentials ranging from 30.2 percent in 1984 to 42.2 percent in 1997. Similar wage differentials between computer users and non-users are obtained for the German and British data.

Regression coefficients such as the ones in Table 3 have led to a large number of studies seeking an explanation for it and to many studies replicating these results for other countries. Borghans and ter Weel (2005) provide an elaborate discussion of all these explanations. The most prominent studies (i) have been using longitudinal data showing that computer technology users were already earning higher wages than nonusers before they adopted computer technology (Entorf and Kramarz, 1997); (ii) have shown that firms adopting advanced technologies earlier on pay higher wages (Doms,

\footnotetext{
${ }^{13}$ The relationship between age and computer use at work is addressed at length in Borghans and ter Weel (2002) for Britain, Weinberg (2002) and Friedberg (2003) for the United States and Aubert, Caroli and Roger (2006) for France.

${ }^{14}$ Weinberg (2000) has explained this observation by arguing that jobs which previously required a great deal of physical strength and stamina have been transformed into more women-friendly jobs after the introduction of computer technology. Also computers seem to be more heavily used in occupations in which women are particularly present.
} 
Dunne and Troske, 1997) and (iii) have shown that it is probably not computer skills per se that determine a correlation between computer use and wages (DiNardo and Pischke, 1997). The main question is why computer users earn higher wages than non-users. Note that we do not argue that computer users earn higher wages because they use the technology at work, we only address that there is a correlation between computer technology use at work and the level of wages.

\section{Combining macro and micro}

So the macro and the micro approaches to understanding computer technology diffusion and the effects on the wage distribution provide different views, with both perspectives unable to explain some of the key characteristics. The macro analyses based on a CES production function suggest that either skilled or unskilled workers benefit from the computer technology, while the micro evidence shows that computer technology is used in all segments of the labor market by all types of workers, but apparently benefits some workers within each group more than others. In this section we propose a way to integrate both approaches by means of a more sophisticated framework and a number of simulations for illustration.

\subsection{Worker heterogeneity}

Splitting the stock of computer technology in computers used by skilled workers and computers used by unskilled workers, a nested production function can be used in which both skilled and unskilled workers use computer technology ${ }^{15}$ The production function of an intermediate product for skilled and unskilled workers then look as follows:

(8a) $Y_{S}=\alpha_{S}\left(\left(\gamma_{S} S\right)^{\rho}+\left(\gamma_{C} C_{S}\right)^{\rho}\right)^{1 / \rho}$

and

(8b) $Y_{U}=\alpha_{S}\left(\left(\gamma_{U} U\right)^{\rho}+\left(\gamma_{C} C_{U}\right)^{\rho}\right)^{1 / \rho}$.

\footnotetext{
${ }^{15}$ A question is whether it is needed to separate skilled and unskilled workers into two groups, or that both groups of labor input could be treated as one single input. However, Borghans and ter Weel (2007) show for the United States that the wage dynamics for skilled and unskilled workers are different in the period 1963-2000.
} 
Together these outputs are inputs in final production:

(8c) $Y=\alpha\left(\left(\gamma_{S} Y_{S}\right)^{\delta}+\left(\gamma_{U} Y_{U}\right)^{\delta}\right)^{1 / \delta}$.

In general, the parameters in the production functions (8a) and (8b) for skilled and unskilled workers could be different. Such a difference would imply a skill bias of technology. In this paper we assume no difference between both production functions, to illustrate that such differences are not needed to generate plausible patterns in computer use and wages.

To allow for individual heterogeneity within both groups, the CES production function can be individualized:

$$
Y_{i}=\left(\left(\gamma_{i} L_{i}\right)^{\rho}+\left(\gamma_{C} C_{i}\right)^{\rho}\right)^{1 / \rho}=\left(\left(\gamma_{i} 1\right)^{\rho}+\left(\gamma_{C} C_{i}\right)^{\rho}\right)^{1 / \rho} .
$$

Each worker provides one unit of labor. Given the price of computers $(p)$, for each worker the optimal investment in computers can be determined. Adding up all workers, $Y_{S}=\sum_{S} Y_{i}$ and $Y_{U}=\sum_{U} Y_{i}$, yields the original CES production functions for skilled and unskilled workers (5a) and (6a) in which $C=\sum C_{i}$ is the input of computers. In this framework each worker produces an intermediate product using his own labor and an individual stock of computer equipment. Workers may differ in the amount of computer equipment they use $\left(C_{i}\right)$ and in their individual productivity $\left(\gamma_{i}\right)$. If the price of computers equipment is given, and if every worker adopts the optimal amount of computer equipment, the outcomes of the aggregate CES function are consistent with this individual behavior, because the optimal investment in computers is a linear function of individual productivity $\left(\gamma_{i}\right): C_{i}^{*}=\frac{\gamma_{i}}{\left(p^{\rho /(1-v)} \gamma_{c}^{-\rho^{2} /(1-\rho)}-\gamma_{c}^{\rho}\right)^{1 / \rho}}$. The challenge is to show that the individual production functions describe individual patterns adequately and to explain between-group differentials using the same individual production function.

To model this feature, we add specific information about the way people use computer technology to the individual production functions described by equations (8). These adjustments can be facilitated using an interpretation of the CES production function introduced by Rosen (1979). In this interpretation the assumption is made that for the production of every unit of output a continuum of tasks has to be fulfilled. This 
continuum is represented by the interval $[0,1]$. There are two inputs (a worker and a computer in this case) who are able to perform these tasks at a different pace. Panel A in Figure 4 shows the time needed to carry out each task. The figure should be read as input 1 (the worker) being best in performing tasks close to 0 (a non-routine task) on the horizontal axis, while input 2 (the computer) being best at tasks close to 1 (a routine task) on the same axis. An appropriate choice for these functions indicating the time needed for each task $x$ is the following:

(9a) $\quad t_{1}=\frac{\rho}{\gamma_{1}(1-\rho)} x^{(1-\rho) / \rho}$

and

(9b) $\quad t_{2}=\frac{\rho}{\gamma_{2}(1-\rho)}(1-x)^{(1-\rho) / \rho}$,

where $t_{1}$ is the time needed to fulfill task $x$ by input 1 , and $t_{2}$ the same for input 2 .

If the supply of inputs is such that $L_{1}$ units of input of type 1 and $L_{2}$ units of input of type 2 are available, the optimal allocation of inputs requires that there is a threshold $\mu$ such that each task to the left (right) of this threshold is performed by input of type 1 (type 2), in such a way that they reach a joint output level $Y$ (see panel B in Figure 4). If there is more input of the first type, this input takes over the tasks of inputs of type 2 that are near the threshold. Their tasks gradually shift to the right to tasks in which they are relatively less productive, as shown in the panels $\mathrm{C}$ and D. Denoting the time needed by input 1 (input 2) to fulfill all the tasks between 0 and $\mu$ (between $\mu$ and 1) for the production of one unit of goods by $T_{1}^{\mu}\left(T_{2}^{\mu}\right)$, for the optimal allocation of inputs a threshold $\mu$ has to be found such that:

$$
\text { (10a) } L_{1}=Y T_{1}^{\mu}=Y \int_{0}^{\mu} \frac{\rho}{\gamma_{1}(1-\rho)} x^{(1-\rho) / \rho} d x=Y \frac{\mu^{1 / \rho}}{\gamma_{1}}
$$

and

$$
\text { (10b) } L_{2}=Y T_{2}^{\mu}=Y \int_{\mu}^{1} \frac{\rho}{\gamma_{2}(1-\rho)}(1-x)^{(1-\rho) / \rho} d x=Y \frac{(1-\mu)^{1 / \rho}}{\gamma_{2}} \text {. }
$$

From conditions (10a) and (10b) the optimal thresholds $\mu$ and $1-\mu$ can be derived: 
(11a) $\quad \mu=\left(\frac{\gamma_{1} L_{1}}{Y}\right)^{\rho}$

and

(11b) $1-\mu=\left(\frac{\gamma_{2} L_{2}}{Y}\right)^{\rho}$.

Adding these two equations together yields the following CES production function:

$$
Y=\left(\left(\gamma_{1} L_{1}\right)^{\rho}+\left(\gamma_{2} L_{2}\right)^{\rho}\right)^{1 / \rho}
$$

We use this framework to illustrate the cooperation between a worker (input 1) and a computer (input 2) by presenting a number of simulations.

\subsection{Simulations}

We now present six sets of simulation results in which we show how the micro and macro conclusions can be reconciled in a unifying framework. We start by presenting the basic approach to the simulations. Then four sets of simulations are presented for five workers within the same labor-market group (i.e., they are perfectly substitutable). Finally, a simulation is presented for between-group wage inequality in which workers are less than perfectly substitutable.

\subsubsection{The basic CES production function}

The simulations are based on parameters for five different individuals. $\rho=\frac{2}{3} ; \gamma_{i}$ varies from 1.25 for the least productive workers, to $1.43,1.67,2.00$, and 2.50 for the most productive worker; 100 tasks are distinguished distributed with equal intervals between $x=0$ and $x=1$. We assume that computer technology becomes cheaper over time, with an annual decrease of the price of 10 percent. This process, documented by e.g., Bresnahan and Greenstein (1996) and Greenwood and Yorukoglu (1997), and used by several authors as the driving force behind computer technology diffusion (e.g., Autor, Katz and Krueger, 1998, Autor, Levy and Murnane, 2003 and Borghans and ter Weel, 2007), is the exogenous factor in our model. We assume this process to be log linear over time. Each worker provides one unit of labor. The supply of computer input for each individual is determined by the price of computer equipment and the marginal 
productivity of each worker. We assume that the supply of computer equipment can be adjusted unlimited. This feature of the model contrasts with the assignment approach as used by Dupuy (2009), Sattinger (1980 and 1993), and Teulings (1995 and 2005) in which the machines that are available - and that vary in quality - are determined exogenously.

There are four variables of interest that change over time when computer technology becomes cheaper. Figure 5 plots these variables for the basic CES case in each of its four panels.

First, when computer technology becomes cheaper the marginal tasks, i.e. the first task that is not performed by the worker but by the computer, shifts downwards. More and more work will be taken over by the computer technology, gradually replacing human labor as an input. In the case of the traditional CES this line is the same for all workers. More productive workers need less time for each task, which implies that they would adopt computer technology later at given prices. Wages for more productive workers are higher though - as every worker-computer combination is paid for its output - leading to the same timing of adoption of computers for certain tasks. Panel A of Figure 5 shows the evolution of the marginal task over time. As computer technology becomes cheaper, in the end, all tasks are performed by computers after some thirty years of time.

Secondly, workers might differ in the total investments in computer equipment. Computer equipment is paid for per time unit of usage; basically workers rent computer technology. Since more productive workers produce more output, they also need more computer time to keep up with their pace. Effectively, more productive workers can be regarded as larger firms, needing more equipment (as the larger farms in David's case (David, 1969)). Panel B of Figure 5 shows how this works in our example of five workers. As computer technology becomes cheaper workers start investing in the technology. Worker 1 (the worker with the highest productivity) invests most and worker 5 (the worker with the lowest productivity) least, because worker 1 is the most skilled worker.

Thirdly, wages respond to the use of computer technology. Wages are determined as the profit of the worker plus his computer minus the costs of computer equipment, which means that every worker is treated as an independent firm. In a competitive market 
employers would assign the same amount of computer equipment to each worker and would pay the same wage. In Panel $\mathrm{C}$ of Figure 5 the log wages are plotted for the five workers, which show the development of wages in relative terms.

Fourthly, since different workers use the computer technology for the same tasks, relative wages remain the same. This is shown in Panel D of Figure 5 which provides the development of wage inequality over time, which is constant and flat. This is consistent with Sattinger (1980), who proves in a Cobb-Douglas case that inequality in log wages does not depend on the price of technology.

\subsubsection{Not every task can be computerized}

An unrealistic feature of this standard CES production function in the Roseninterpretation is that every task in the production process can be computerized. The explicit micro-foundation of the production function allows us to change the production process and drop this feature. Figure 6 shows the alternative. We now assume that only 50 percent of all tasks can be computerized, with the time needed for tasks going to infinity when the tasks gets close to 0.5 . The function for the performance of tasks we apply to get this process going is $t_{2}=\frac{\rho}{\gamma_{2}(1-\rho)}\left(\frac{1}{x-0.5}\right)^{(1-\rho) / \rho}$.

Unlike the standard CES production function this production process cannot be solved analytically, so the characteristics have to be simulated. Figure 7 shows the results; the panels are similar to the ones displayed in Figure 5. Qualitatively the results of the CES production function remain unaltered, but the use of computer technology for new tasks now moves slower, converging to 0.5 when compared to the results presented for the standard CES case above (e.g., Panel A). The development in the other dimensions remains similar and wage inequality does not increase. This model basically yields similar results compared to the standard CES case.

It is interesting to note that in the process of computer diffusion, wages are much less affected than when the diffusion is complete. The reason for this is that computer technology is adopted by each of the five workers at the point in time when the costs equal the benefits. This means that there will be no gains in terms of profits (i.e., wages) at the point of adoption but only after a while when computer technology becomes 
cheaper.

This, together with the previous illustration, makes clear that analysis of the pure CES production function is not very adequate for explaining the documented changes in relative wages as a result of the diffusion of computers in the labor market. There are no differences in the timing of adoption of computers and no within group differences are generated. Borghans and ter Weel (2004) have shown that there are three reasons why adoption decisions might be different and generate within-group differences: (1) People differ in their ability to work with computers, (2) people might have a comparative advantage in tasks that cannot be carried out by computer technology, and (3) there might be fixed costs in using a computer, i.e. the costs for someone who uses a computer intensively might not be equal to the costs for someone who uses the technology occasionally only. The framework of an explicit description of the production process makes it possible to add features to the model that make its description more adequate. Now, let us move to more sophisticated applications in which we discuss the consequences of these effects.

\subsubsection{Computer skills}

There can be heterogeneity in computer skills across workers. Panel A in Figure 8 shows how computer skills can be implemented in our framework. The set up is the same as before, but we add that workers need to spend time for each task that is performed by the computer. This represents time needed to operate the computer (timec) and is comparable to the time for communication between workers in Borghans and ter Weel (2006) when the production of a good is carried out by several workers. The time needed is the same for each task, but differs across workers. We assume that more productive workers need less time to operate the computer because they have a higher level of computer skills. This can be regarded as a causal and very narrow interpretation of the estimation results in Table 3 above. It is assumed that the most skilled worker needs 13 time units to operate the computer while less skilled workers need 17, 21, 25, and 29 units, respectively.

Panel B in Figure 8 shows how a worker spends his time. The dark areas represent the time spent for each task, with the computer performing task 2 and the worker task 1. 
The threshold is around 0.37 . The dark grey area to the left of the threshold is the time the worker spends working on task 1 and the light grey area to the right of the threshold is the time used to operate the computer.

Figure 9 shows the effects of incorporating computer skills into the simulation model. Panel A reveals that workers now adopt computer technology more gradually. In addition, the more skilled workers use the computer technology for a larger fraction of their jobs and more intensively for each task (Panel B). The wage gains for the heavier users in the longer term are higher because they outperform the others in terms of productivity (Panel C). This means that wage inequality goes up, reflecting in this case the difference in productivity due to the difference in computer skills (Panel D).

\subsubsection{Complementary skills}

An important question is whether the time needed to operate a computer is sufficiently large to explain a substantial increase in wage inequality as documented for example for the United States since the 1980s. An alternative explanation put forward in the literature is one that argues that skilled workers have a comparative advantage in tasks that are relatively hard to computerize. In terms of our simulation model we assume that workers of higher skill levels need relatively less time to perform the non-routine tasks. To obtain this result we use the function $t_{1}=\left(\left(\frac{\rho}{\gamma_{1}(1-\rho)}\right)(1-x)+x\right) x^{(1-\rho) / \rho}$.

Figure 10 shows that the curvature of the time-curve for workers is different for different skill levels. The curve timela represents the time needed to perform the tasks for a relatively skilled worker and time2a is the time a relatively unskilled worker needs to carry out the tasks. The two lines are such that in the simulation timela is the time requirement for the most skilled worker and timelb the time requirement for the least skilled worker. The other three workers are in between.

Figure 11 shows the results of the simulation with different time requirements to carry out the job. Qualitatively the results are similar to the results of the simulation with computer skills, but more feasible to establish larger increases in long-term wage inequality between the five workers in this economy. 


\subsubsection{Fixed costs of computers}

Unlike the standard CES production function, models with computer skills and complementary skills are able to explain differences in the timing of the diffusion of computer technology. To obtain these results the assumption is needed that computer skills or complementary skilled are positively correlated with the productivity level in general, i.e. more skilled workers need to have not only an absolute but also a comparative advantage in computer skills or in (some kinds of) complementary skills. Since operating a computer might be difficult, but certainly is not a task with a very high cognitive demand, this seems more plausible for complementary skills. Furthermore, the simulations show that although there is some difference in the timing of computer technology adoption, workers with different skill levels still follow very quickly in adopting computer technology. They use the computer for almost the same tasks. The main difference is in the computer time. Finally, these models predict wage inequality to increase only once computer diffusion is almost complete. In the early stage of computer diffusion relative incomes remain almost the same. This seems inconsistent with trends in wage inequality as documented for example in Figure 3 for the United States.

Apparently, these models give only little advantages to more skilled workers. Skilled workers make more use of computers, but at the same time also have to pay more for the computer time they need. Therefore, as long as the marginal costs of using a computer are close to the marginal benefits, the profits (wage gains) are low. In practice, however, computers stand idle most of the time. Computers are not paid for each minute of computer time but essentially for every worker the same costs have to be incorporated by the employer, irrespective of usage. Hence, computer technology use comes with fixed costs. We assume that the costs depend on the tasks that have to be performed.

Figure 12 presents the simulation results with fixed costs for computer technology use. We assume that the costs for computer use only depend on the number of tasks it can perform, and not on the computer time per task. This implies that more sophisticated applications are more expensive, but no extra costs are paid for using these applications more extensively. In these simulations workers would very quickly switch from not using a computer to using a computer for all tasks if the functional form would be the standard CES production function. We therefore use the functional form in which not all tasks can 
be computerized, such as shown in Figure 6.

This alternative approach had quite substantial implications. Panel A of Figure 12 shows that the difference in timing of the adoption of computers increases substantially. Once the computer is adopted there are no differences in the investments. The main difference between more and less productive workers is obtained from the point in time at which they adopt the computer technology. As a result, wage inequality starts much earlier in this scenario than in the case where computer skills or complementary skills generate inequality. Once all workers use computer technology in their jobs, the most productive worker has the advantage that computer technology is cheaper relative to his wage. The computer technology induces the same relative increase in productivity for all workers, while the costs are the same in absolute terms. As a consequence, when computer costs converge to zero the increase in wage inequality will go down again and ultimately disappear.

\subsubsection{Interaction between skilled and unskilled workers}

Until now we distinguished only one group of workers in the simulations. In the generalization of the models by Katz and Murphy (1992) and Krusell et al. (2000) as described in equations (8), skilled and unskilled workers are distinguished and their inputs are not fully substitutable. The previous findings of the simulations can be regarded as results for within-group wage developments.

Borghans and ter Weel (2007) provide empirical evidence that the wage development of skilled and unskilled workers is different, reflecting differences in the supply of effective labor for both groups. If we assume that both skilled and unskilled workers face a similar diffusion process of computers, productivity within each skill group can be determined by $Y_{S}=\sum_{S} Y_{i}$ and $Y_{U}=\sum_{U} Y_{i}$. When both intermediate outputs are less than perfect substitutes, total output equals: $Y=\alpha\left(\gamma_{S} Y_{S}^{\rho}+\gamma_{U} Y_{U}^{\rho}\right)^{1 / \rho}$.

The effects of combining two skill groups for the different scenarios are depicted in Figures 13-16. For each skill group five workers are included in the simulation. There is some overlap in productivity between both groups. $\gamma_{i}$ of unskilled workers again varies from 1.25 for the least productive workers, to $1.43,1.67,2.00$ and 2.50 for the most 
productive worker. For skilled workers $\gamma_{i}$ rangers from 1.67 for the least productive workers, to 2.00, 2.50, 3.33 and 5.00 for the most productive worker. So, productivity of three out of five workers overlaps. The elasticity of substitution between skilled and unskilled workers is 1.67 and $\gamma_{S}$ is set equal to 2.17 to compensate for the higher productivity and thereby higher supply of efficiency units of skilled labor. In the simulations this means that the supply of skilled and unskilled labor is about equal before computerization.

Figure 13 shows that distinguishing between skilled and unskilled workers has no effect for the standard CES production function. Since all workers adopt computer technology at the same pace and increase productivity equally in relative terms, their wages increase at the same pace and total production of the intermediate good of skilled and unskilled workers also increases at the same pace. As a result, the overall production function remains balanced.

The developments are different when computer skills are relevant for computer adoption, as shown in Figure 14. In these simulations within-group wage inequality for skilled and unskilled workers follows the patterns as depicted earlier. But, since more productive workers benefit more from using computer technology than less productive workers, also the intermediate output of skilled workers increases more than the intermediate output of unskilled workers. In the overall CES production function this implies a shift of skilled versus unskilled wages in favor of the unskilled workers. This effect to some extent counterbalances the increase in between-group wage inequality. An interesting feature of the model is that when comparing a skilled and an unskilled worker with the same initial wage, the unskilled worker benefits more from computerization than the skilled worker. Both workers have the same advantage for individual productivity from computer technology adoption, but the price of skilled intermediate output falls relatively to unskilled output due to the relative increase in skilled output. The model with complementary skills leads to qualitatively similar patterns, as shown in Figure 15. When skilled workers start to use computers, their output increases which lowers their wages. Only when unskilled workers also start to use computers, their output also increases, counterbalancing this trend and pushing the between-group wage difference up again. 
Finally, Figure 16 shows how wage inequality develops in the scenario where computer costs are fixed. Here too the wages of skilled workers go down initially as this group starts to adopt computer technology. Especially skilled workers who do not adopt computer technology themselves yet, face relative wage losses when their more productive skilled colleagues adopt a computer and increase the level of output of skilled labor in efficiency units. This has a negative impact on the price of the skilled output. Later on, when unskilled workers adopt computer technology, this trend reverses and finally when diffusion is complete the between-group wage inequality moves back to its initial value. When computer costs converge to zero the relative differences between all workers have disappeared.

\section{Interpretation and conclusions}

We have investigated to what extent a standard nested CES production function can explain the recent trend in within-group and between-group wage inequality as a result of the computerization of the labor market. An important finding is that when every worker can invest in computer technology efficiently and given his own productivity, the CES framework is not generating any change in wage inequality whatsoever. As a result, the standard macro framework typically assumes that computer technology either only affects the productivity of skilled workers - with computer technology being a complement - or the productivity of unskilled workers - with computers being a substitute to skilled labor inputs. Micro evidence, though, is not in line with such a model. Both skilled and unskilled workers adopt computer technology, although at different paces. Next, there are clear changes in within-group wage inequality that cannot be accounted for by this standard CES production function approach.

We show that the CES production function framework can be adjusted by incorporating either computer or complementary skills that give advantages to more productive workers or by taking into account the fact that computer costs are to a large extent fixed costs that have to be paid by each worker, leading to a relative advantage for more productive workers. The models with skill advantages generate patterns in which wage inequality rises when computer adoption is close to completion. The increased wage inequality is permanent in these models. In case of fixed costs, wage inequality 
increases as soon as the first computers are used. Eventually, the increase in wage inequality will disappear when computer costs converge to zero, taking away the relative advantages of more productive workers.

Taking into account that not all workers in the labor market are full substitutes leads to interesting dynamics. For a group that adopts computer technology earlier on the output of intermediate goods will expand relative to the other group, reducing the price of this output and therefore the wages of its group members. Especially skilled workers who did not yet adopt computer technology will face wage reductions when their more productive skilled coworkers already have adopted the new technology.

These simulations with advantages to adopt computer technology for more productive workers in the short run generate wage patterns that are similar to a model in which computers are only complementary to skilled workers. An important difference is that in the long run also the group of less productive workers will start to adopt the technology counterbalancing many of the effects. So, while a traditional CES framework predicts the change in between-group wage inequality to further increase over time, these more sophisticated models predict that most of the changes in between-group wage inequality are temporary in nature and disappear when other workers also start to adopt computers.

This result brings us back to the seminal contributions of Griliches (1957) and David (1969) where we started from and on which we build out approach of computer technology diffusion. These papers suggest that differences between farmers in their awareness to adopt better farming techniques and differences in the between-state adopting patterns yield some states to be below their production frontier for some time in the adoption of new technology. Patterns of computer technology adoption show similar patterns across countries, initially suggesting that the United States were leading in computer adoption and those European countries would be falling behind in the use of computer technology. The analyses show that these patterns are not necessarily inefficient. Like the optimal adoption of hybrid seed might depend on farm size, the optimal adoption of computer technology might depend on a worker's productivity (and as a result the country's wage distribution). As a consequence, more productive workers will adopt computer technology first, but when other workers adopt the same technology 
later on they might experience similar advantages. Borghans and ter Weel (2002) have shown that wages are indeed very good predictors for computer adoption between wage groups.

For example, Figure 17 shows for Britain in 1997 that the adoption rates for each age group very much resemble the age-wage structure. The wage structure is also able to explain differences in computer technology adoption between countries, as is shown in Figure 18 (which is taken from Borghans and ter Weel, 2007). In the panels of this figure, computer adoption rates for the United States and Germany are conditioned on wages. The figure reveals that conditional on wages, the adoption rates are very similar. This implies that the initial advantage of U.S. workers in computer technology adoption was likely a result of the wider wage distribution in the United States. If there are more workers with very high wages there will also be more early adopters. When the diffusion of computer technology continued, the same mechanism made the German workers take over in the rate of computer technology adoption. Lower wage inequality in Germany implies fewer very low and high paid workers and also fewer workers who do not use computer technology to save on their expensive labor at present.

Lex Borghans, Department of Economics and ROA, Maastricht University, PO Box 616, 6200MD Maastricht, the Netherlands.

Bas ter Weel, CPB Netherlands Bureau for Economic Policy Analysis, PO Box 80510, 2508GM The Hague, the Netherlands

\section{References}

Acemoglu, D. 2002. "Technical change, inequality, and the labor market", Journal of Economic Literature 40:7-72.

Acemoglu, D. 2003. "Cross-country inequality trends", Economic Journal 113:F121F149.

Aubert, P., E. Caroli and M. Roger. 2006. "New technologies, organisation and age: firmlevel evidence", Economic Journal 116:F73-F93.

Autor, D.H. and D. Dorn. 2008. "Inequality and specialization: the growth of low-skill service jobs in the United States", Working Paper, MIT Department of Economics.

Autor, D.H., L.F. Katz and M.S. Kearney. 2006. "The polarization of the U.S. labor market", American Economic Review 96:189-194.

Autor, D.H., L.F. Katz and M.S. Kearney. 2008. "Trends in U.S. wage inequality: 
revising the revisionists", Review of Economics and Statistics 90:300-323.

Autor, D.H., L.F. Katz and A.B. Krueger. 1998. "Computing inequality: have computers changed the labor market?", Quarterly Journal of Economics 113:1169-1213

Autor, D.H., F. Levy and R.J. Murnane. 2003. "The skill content of recent technological change: an empirical investigation", Quarterly Journal of Economics 118:12791333.

Berman, E., J. Bound and S.J. Machin. 1998. "Implications of skill-biased technological change: international evidence", Quarterly Journal of Economics 113:1245-1279.

Borghans, L. and B. ter Weel. 2002. "Do older workers have more trouble using computers than younger workers?", Research in Labor Economics 21:139-173.

Borghans, L. and B. ter Weel. 2004. "What happens when agent $T$ gets a computer? The labor market impact of cost efficient computer adoption", Journal of Economic Behavior \& Organization 54:137-151

Borghans, L. and B. ter Weel. 2005. "How computerization has changed the labour market: A review of the evidence and a new perspective", in L. Soete and B. ter Weel, eds., The economics of the digital society. Cheltenham: Edward Elgar, pp. 219-247.

Borghans, L. and B. ter Weel. 2006. "The division of labour, worker organisation and technological change", Economic Journal 116:F45-F72.

Borghans, L. and B. ter Weel. 2007. "The diffusion of computers and the distribution of wages", European Economic Review 51:715-748.

Bresnahan, T.F. 1999. Computerisation and wage dispersion: an analytical reinterpretation", Economic Journal 109:F390-F415.

Bresnahan, T.F. and S. Greenstein. 1996. "Technical progress and co-invention in computing and in the uses of computers", Brookings Papers: Microeconomics 183

David, P.A. 1969. "A contribution to the theory of diffusion", Research Center in Economic Growth Memorandum no. 71, Stanford University.

DiNardo, J. and J.-S. Pischke. 1997. "The return to computer use revisited: have pencils changed the wage structure too?", Quarterly Journal of Economics 112:291-303.

Doms, M., T. Dunne and K.R. Troske. 1997. "Workers, wages, and technology", Quarterly Journal of Economics 112:253-290.

Dupuy, A. 2008. "A Microfoundation for Production Functions: Assignment of Heterogenous Workers to Heterogenous Jobs", IZA working paper 3312.

Dupuy, A. 2009. "The assignment of workers to tasks, wage distribution and technical change: a critical review", Journal of Income Distribution, this issue.

Dupuy, A. and P.M. Marey. 2008. "Shifts and twists in the relative productivity of skilled labor", Journal of Macroeconomics 30:718-35.

Entorf. H. and F. Kramarz. 1997. "Does unmeasured ability explain the higher wages of new technology workers?", European Economic Review 41:1489-1509.

Freeman, R.B. and L.F. Katz. 1995. Differences and changes in wage structures. Chicago: Chicago University Press.

Friedberg, L. 2003. "The impact of technological change on older workers: evidence from data on computers", Industrial and Labor Relations Review 56:511-529.

Geroski, P. 2000. "Models of technology diffusion", Research Policy 29:603-625.

Gottschalk, P. and M. Joyce. 1998. "Cross-national differences in the rise in earning 
inequality: market and institutional factors", Review of Economics and Statistics 80:489-502.

Gottschalk, P. and T. Smeeding. 1997. "Cross-national comparisons of earnings and income inequality", Journal of Economic Literature 35:633-687.

Greenwood, J. and M. Yorukoglu. 1997. “1974”, Carnegie Rochester Conference Series on Public Policy 46:49-95.

Griliches, Z. 1957. "Hybrid corn: an exploration in the economics of technological change", Econometrica 25:501-522.

Hollanders, H. and B. ter Weel. 2002. "Technology, knowledge spillovers, and changes in employment structure: evidence from six OECD countries", Labour Economics 9:579-599

Jorgenson, D.W. 2001. "Information technology and the U.S. economy", American Economic Review 91:1-32.

Katz, L.F. and D.H. Autor. 1999. "Changes in the wage structure and earnings inequality", in Handbook of Labor Economics, vol. 3. O. Ashenfelter and D. Card, eds, Amsterdam: North-Holland, pp. 1463-1555.

Katz, L.F. and K.M. Murphy. 1992. "Changes in relative wages: supply and demand factors", Quarterly Journal of Economics 107:35-78.

Krueger, A.B. 1993. "How computers have changed the wage structure: evidence from microdata, 1984-1989”, Quarterly Journal of Economics 108:33-60.

Krusell, P., L. Ohanian, V. Rios-Rull and G.L. Violante. 2000. "Capital-skill complementarity and inequality: a macroeconomic analysis", Econometrica 68:1029-1053.

Machin, S.J. and J. Van Reenen. 1998. "Technology and changes in skill structure: evidence from seven OECD countries", Quarterly Journal of Economics 113:1216-1244.

Rosen, S. 1979. "Substitution and division of labour", Economica 45:235-250.

Sattinger, M. 1980. Capital and the distribution of labor earnings, Contributions to Economic Analysis 126, Amsterdam: North-Holland.

Sattinger, M. 1993. "Assignment models of the distribution of earnings", Journal of Economic Literature 31:831-880.

ter Weel, B. 2006. "IT diffusion and industry and labour-market dynamics", Economic Journal 116:F1-F9.

Teulings, C.N. 1995. "The wage distribution in a model of the assignment of skills to jobs", Journal of Political Economy 103:180-215.

Teulings, C.N. 2005. "Comparative advantage, relative wages, and the accumulation of human capital", Journal of Political Economy 113:425-461.

Weinberg, B.A. 2000. "Computer use and the demand for female workers", Industrial and Labor Relations Review 53:290-308.

Weinberg, B.A., 2002. "Experience and technology adoption", Working Paper, Ohio State University. 
Figure 1

The diffusion of hybrid seed in five U.S. states

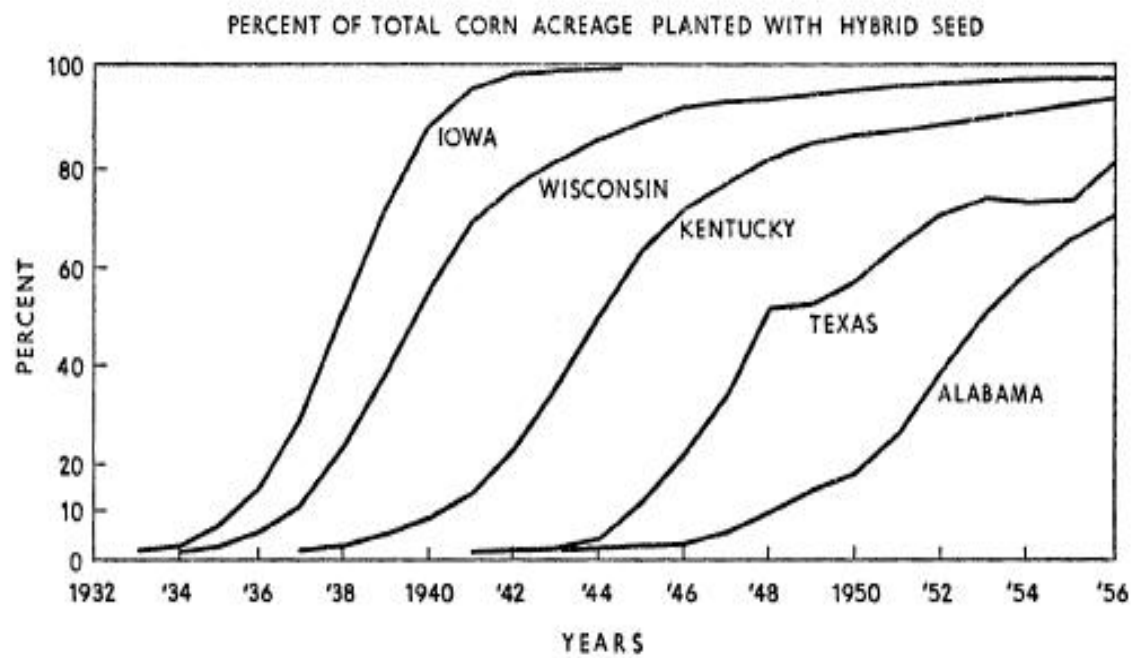

Figure 1.-Percentage of Total Corn Acreage Planted with Hybrid Seed. Source: U.S.D.A., Agricultural Statistics, various years.

Source: Griliches (1957) 
Figure 2

Computer diffusion in Britain, Germany and the United States since the 1980s

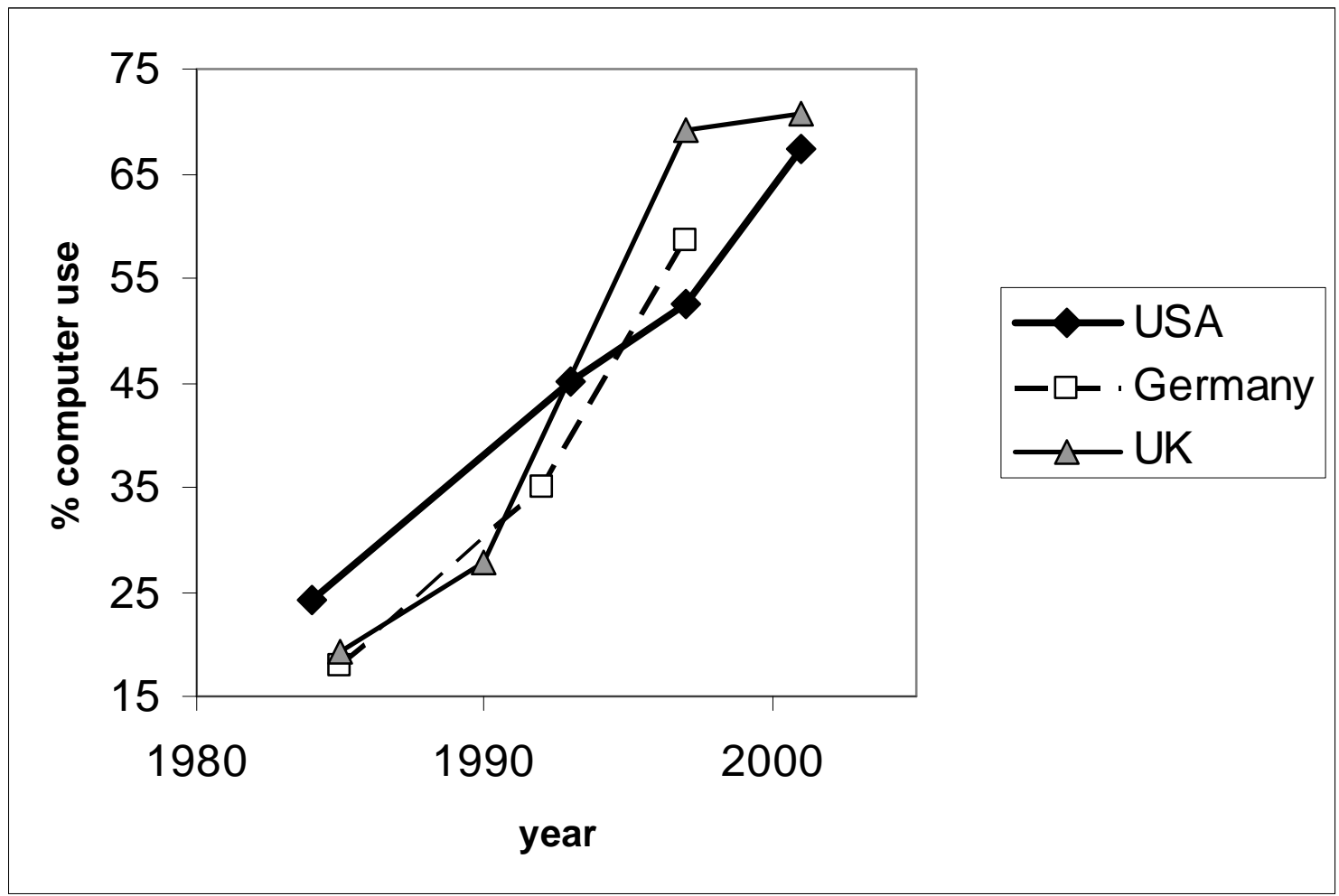

Note: The data for Germany are taken from the Qualification and Career Survey. The British data are from the British Social Attitudes Survey for 1985 and 1990 and the British Skills Survey for 1997 and 2001. The U.S. data are from the October Supplements to the Current Population Surveys for 1984, 1993 and 1997 and the September Supplements to the Current Population Surveys in 2001. 


\section{Figure 3}

The actual log wage premium for skilled workers in the United States, 1963-2002, and predictions for 1963-2010 based on information until 1987 or 2002.

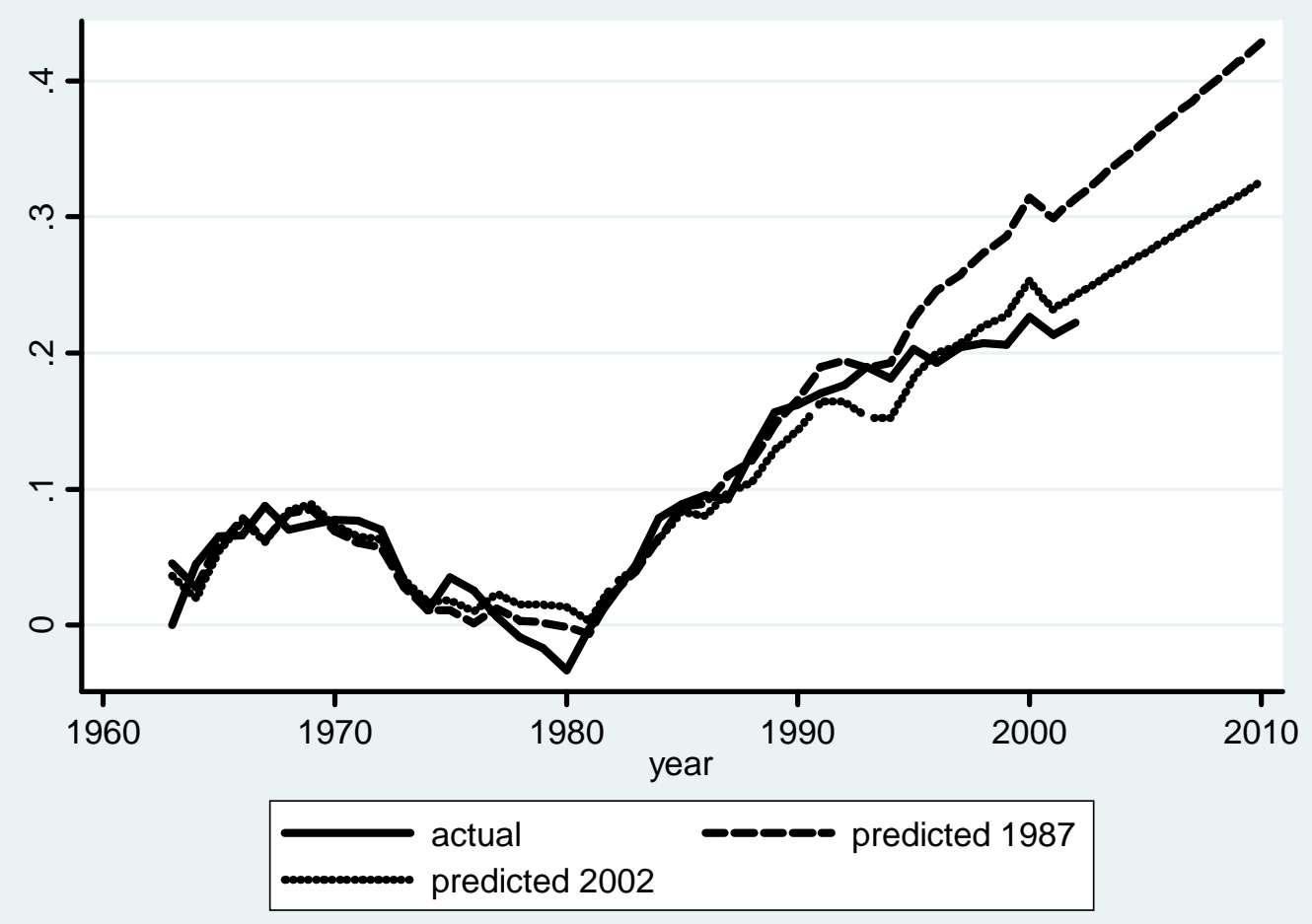


Figure 4

Illustration of the basic simulation model
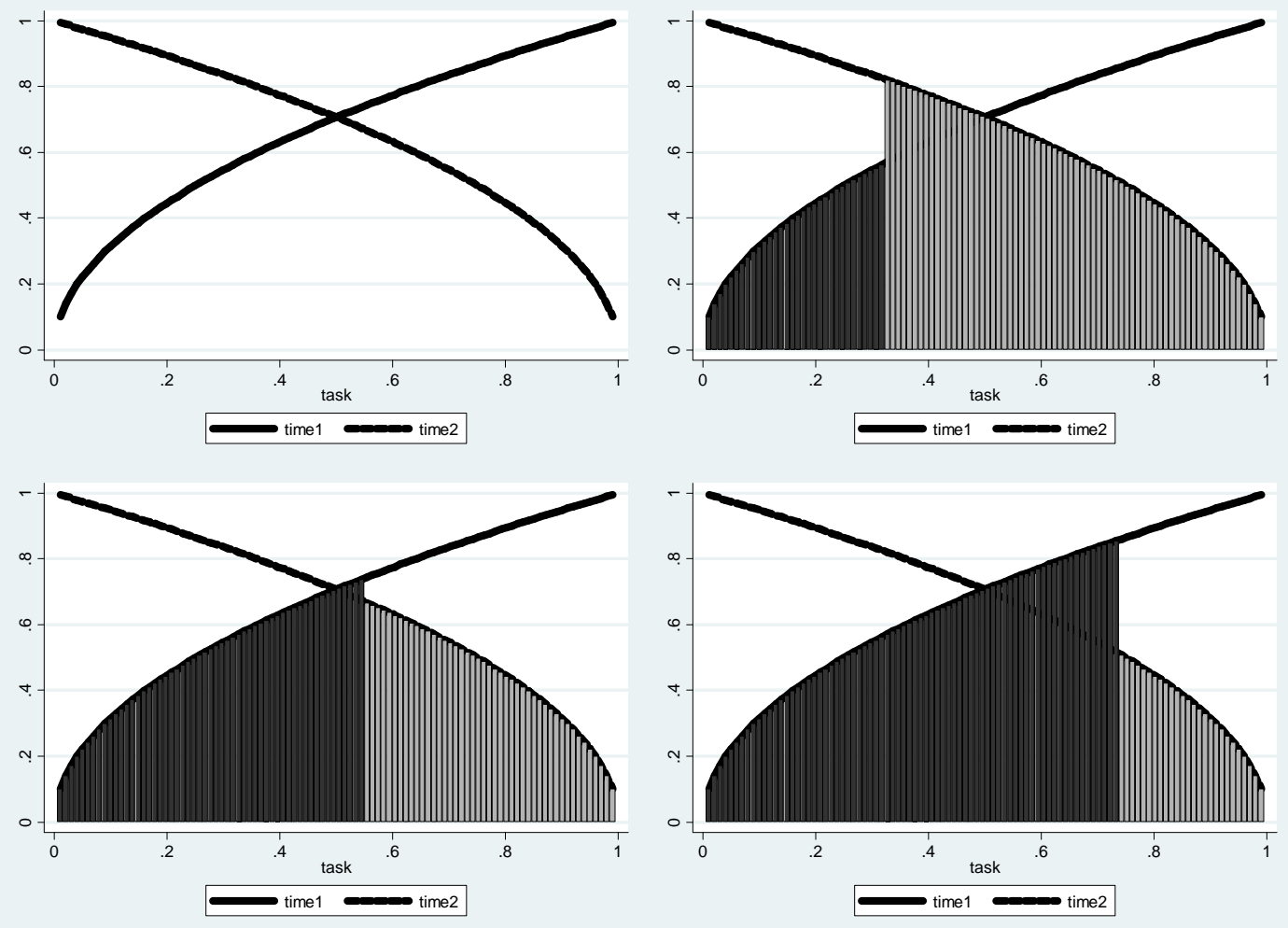
Figure 5

The basic CES case
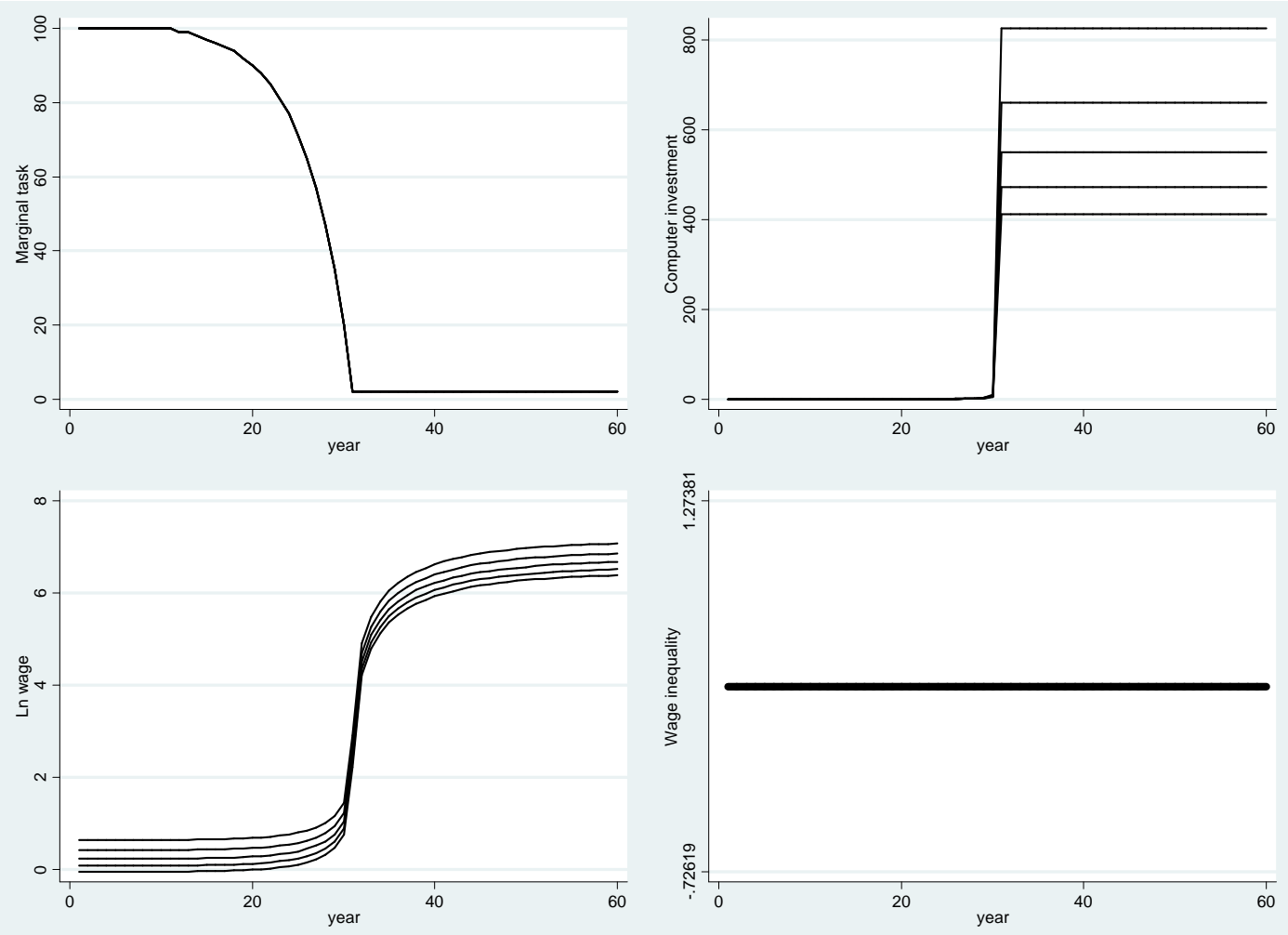
Figure 6

Not all tasks can be computerized

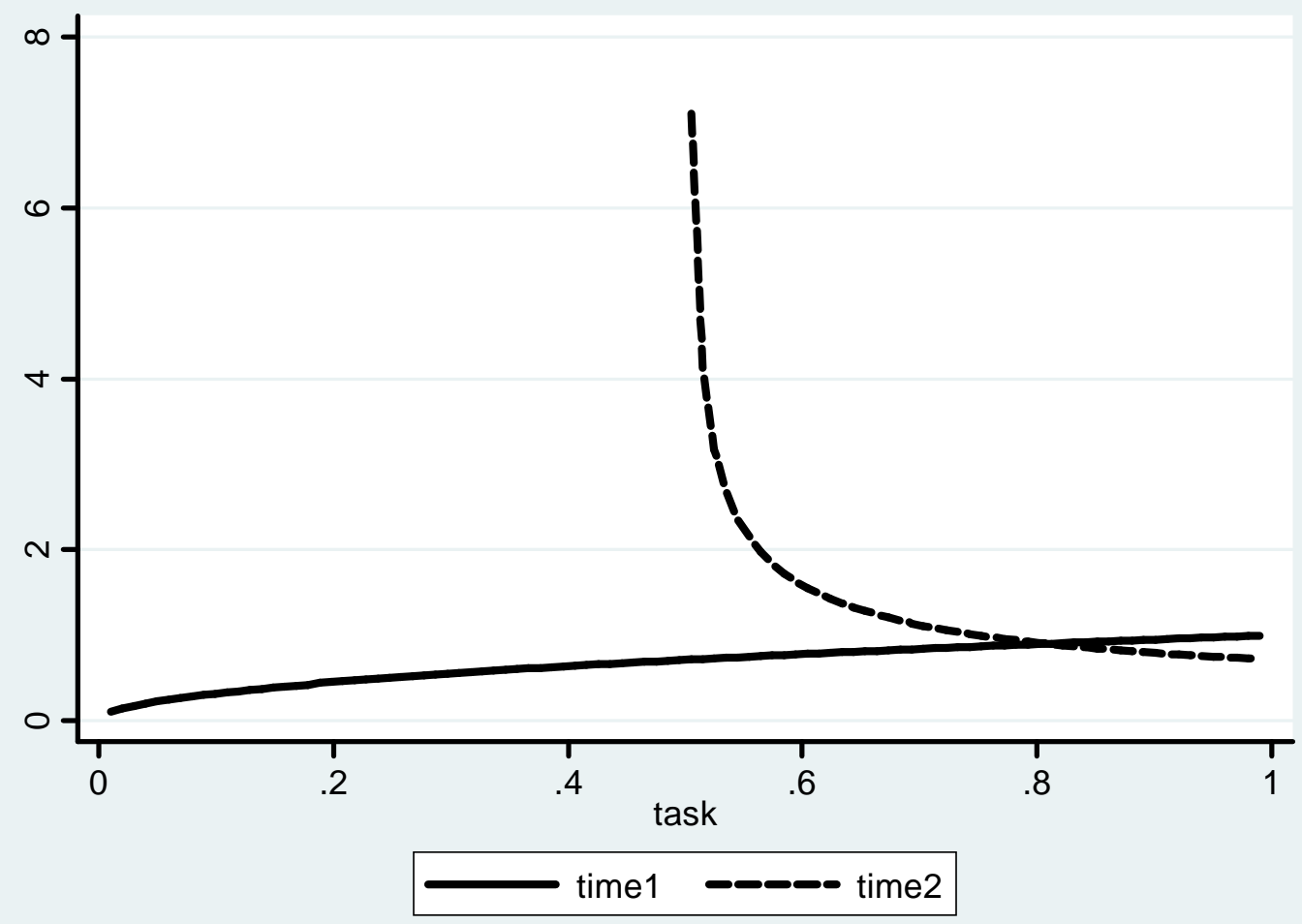


Figure 7

Simulation results when not all tasks can be computerized
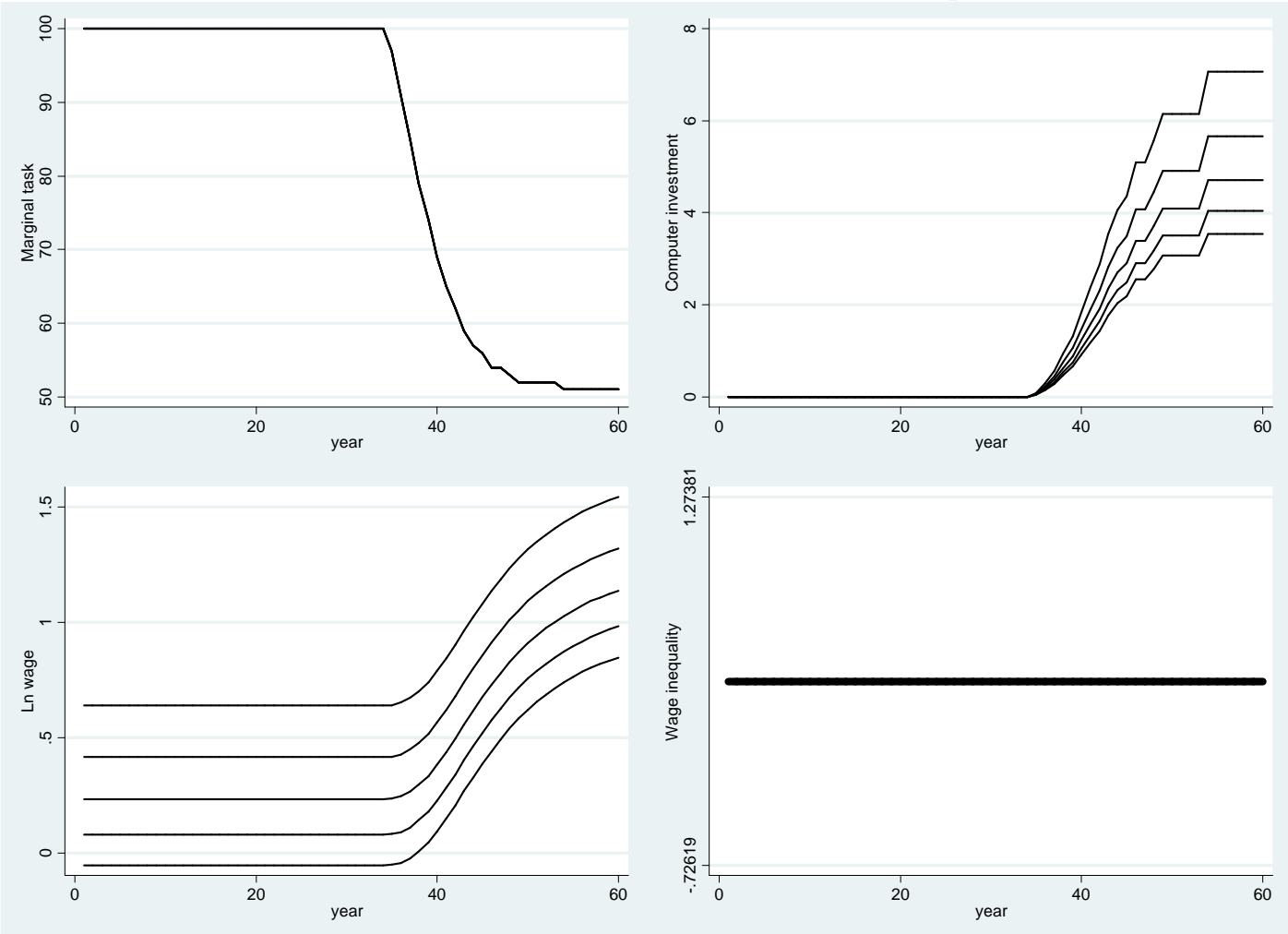
Figure 8

Heterogeneity in computer skills across workers
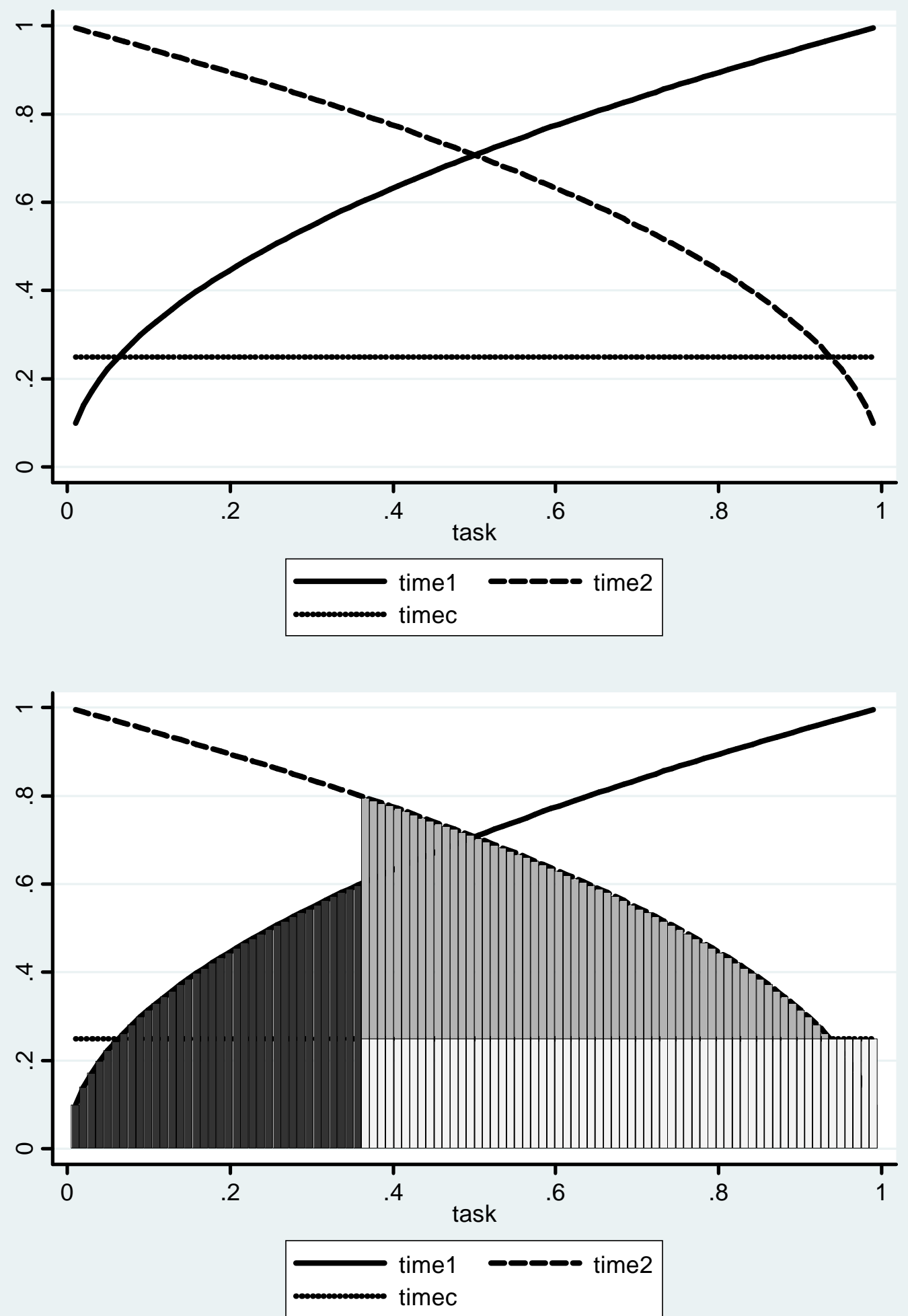
Figure 9

Simulation results when there is heterogeneity in computer skills
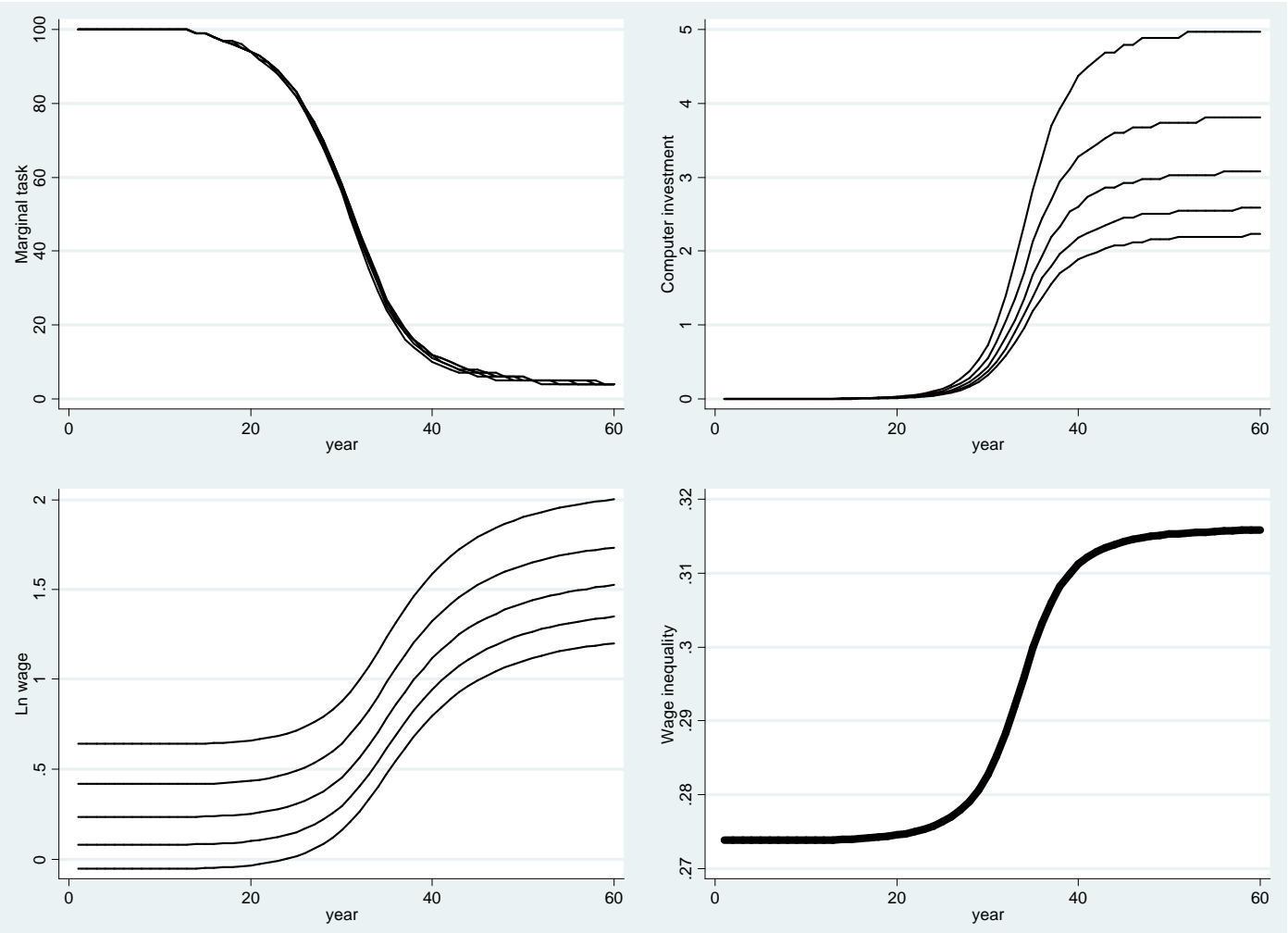
Figure 10

Computer-skill complementarity

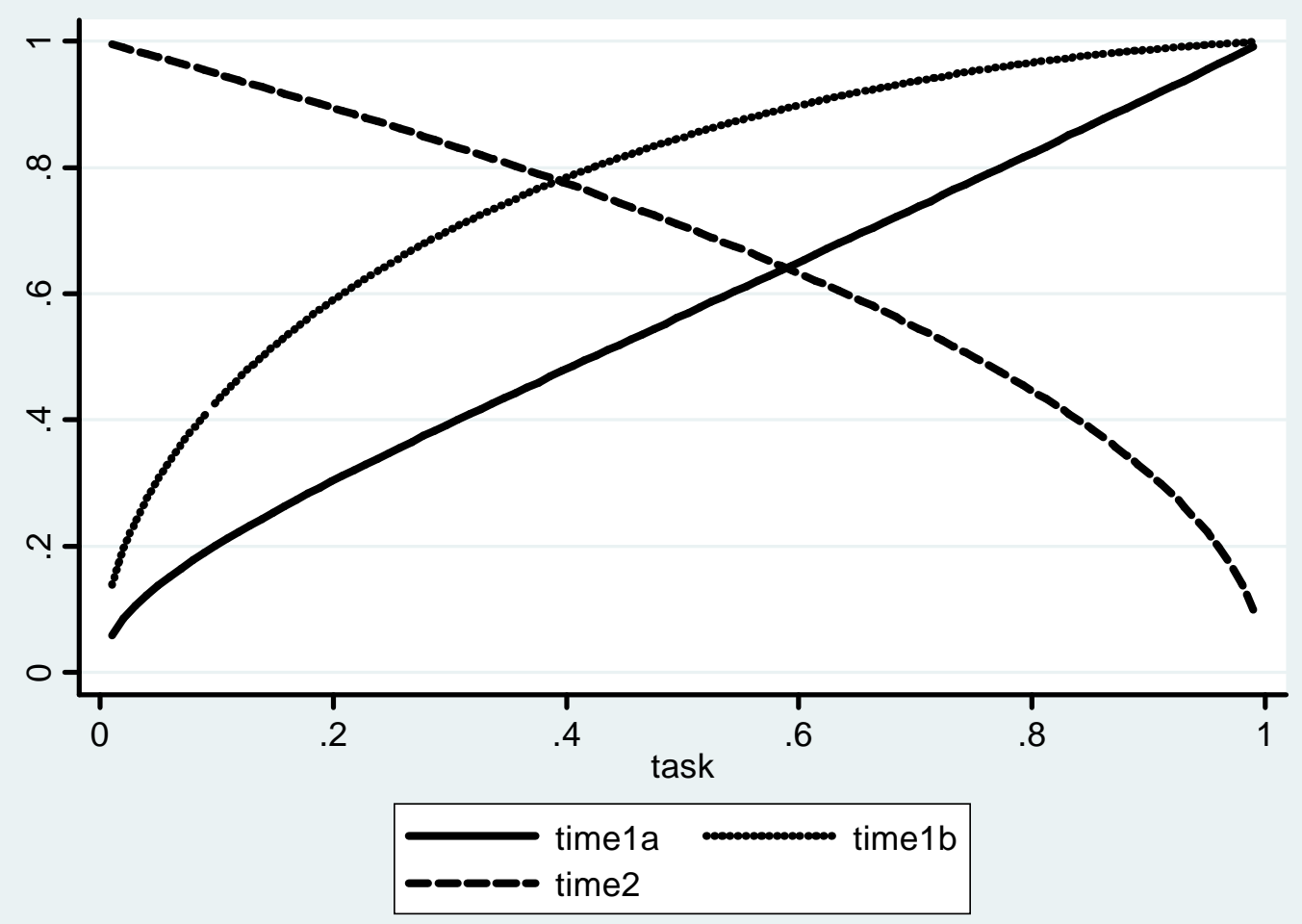


Figure 11

Simulation results with computer-skill complementarity
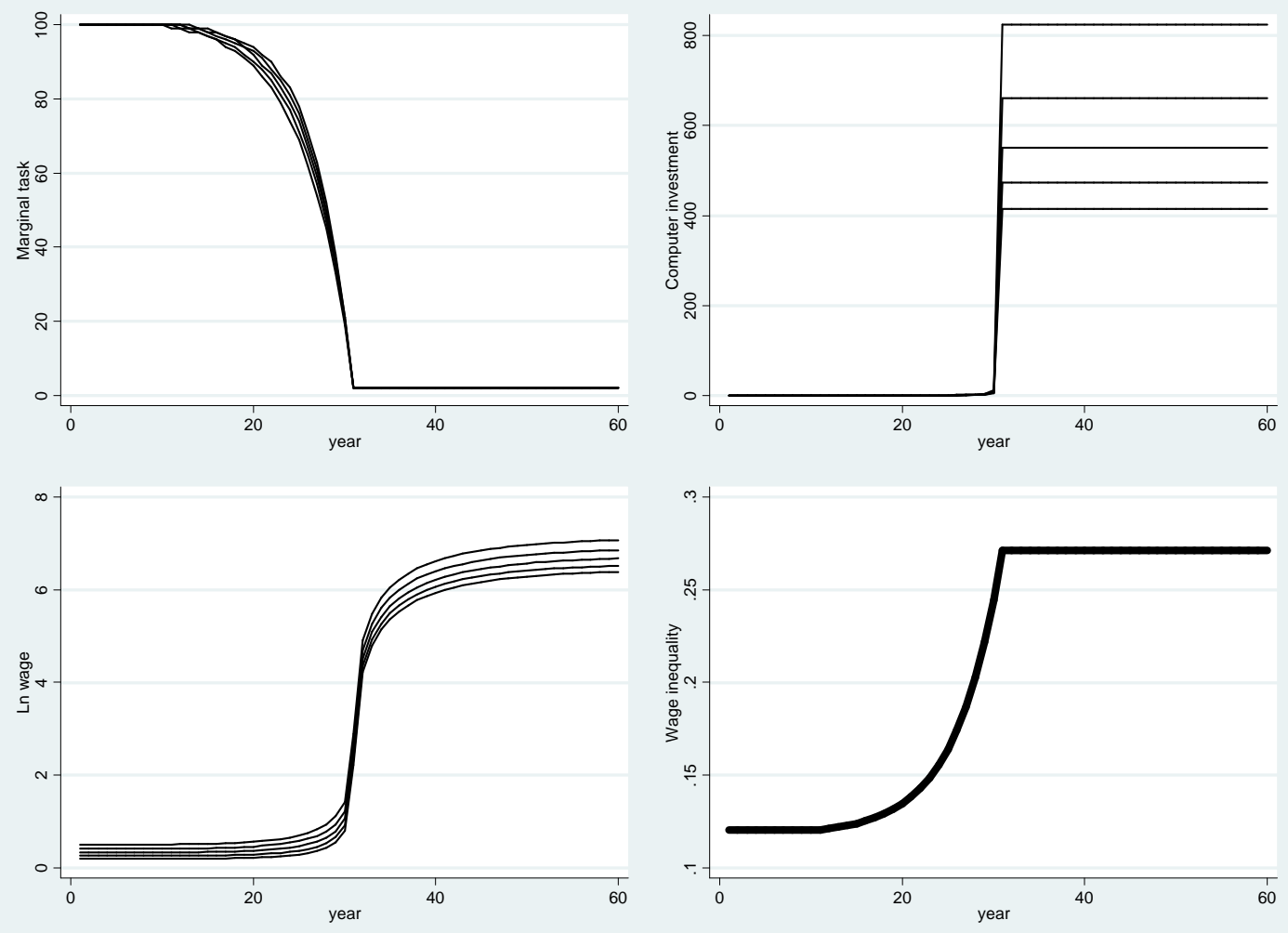
Figure 12

Simulation results with fixed costs for computer technology use
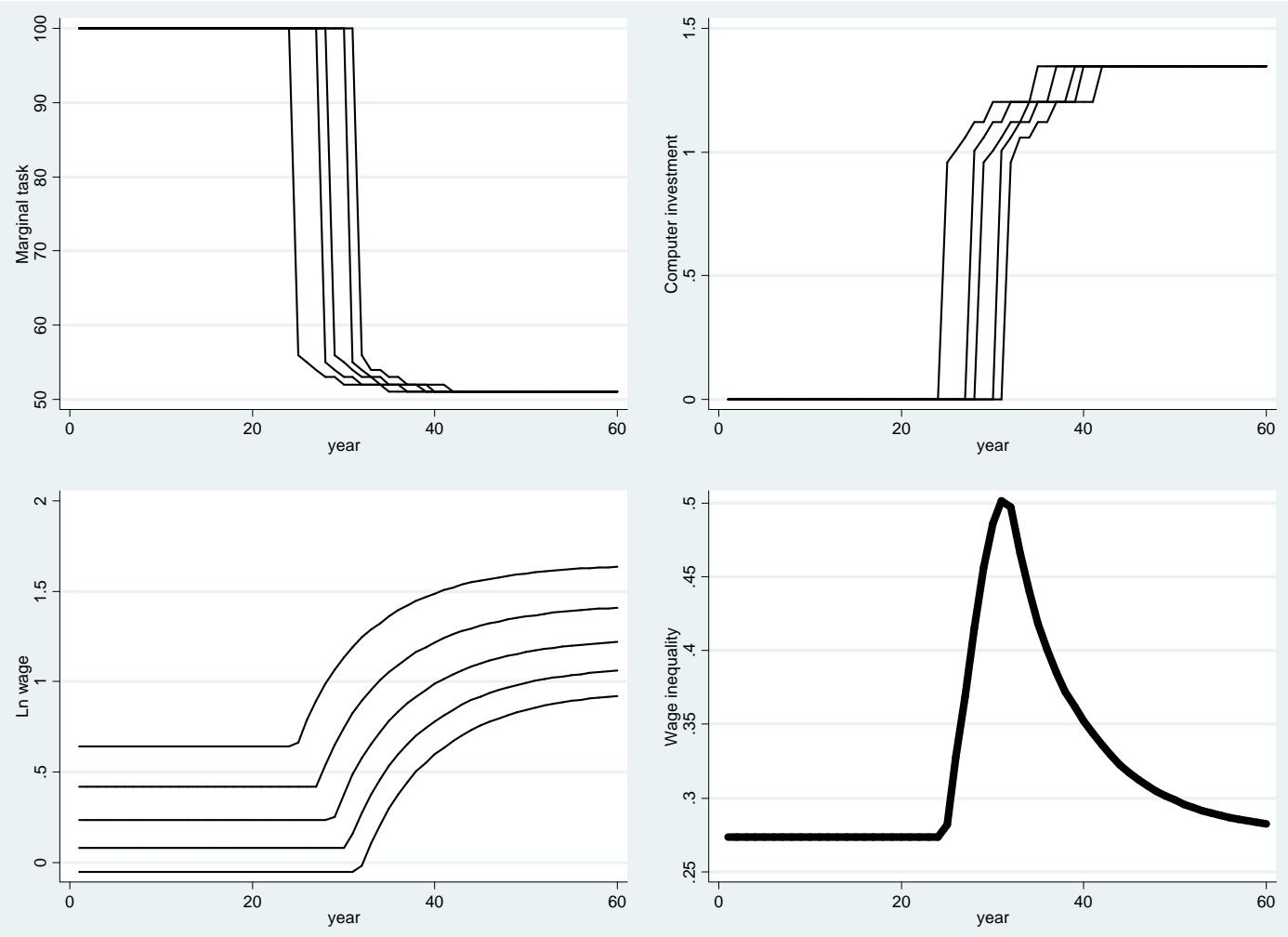


\section{Figure 13}

The basic CES case when workers are not perfectly substitutable
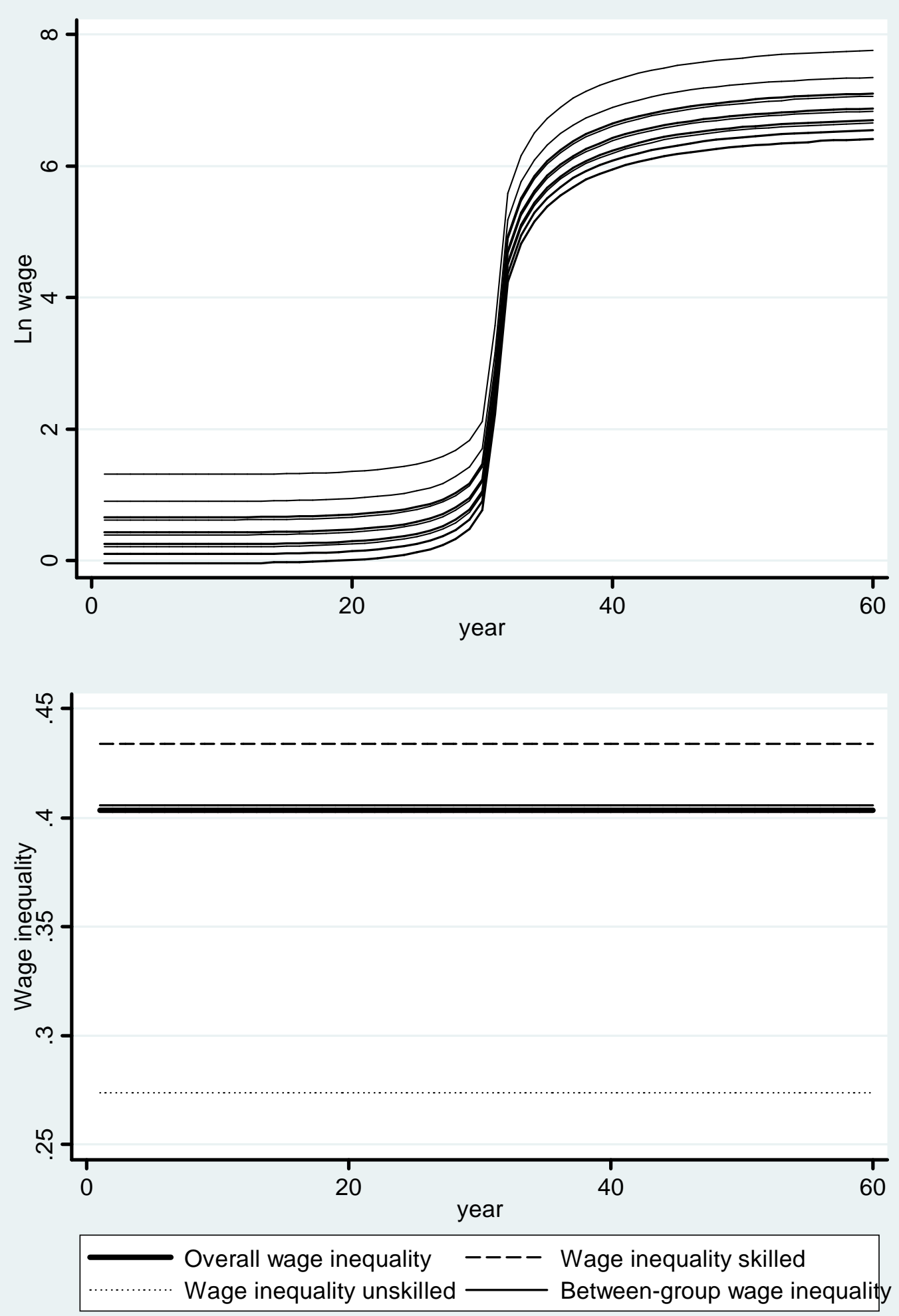


\section{Figure 14}

The case with differences in computer skills when workers are not perfectly substitutable
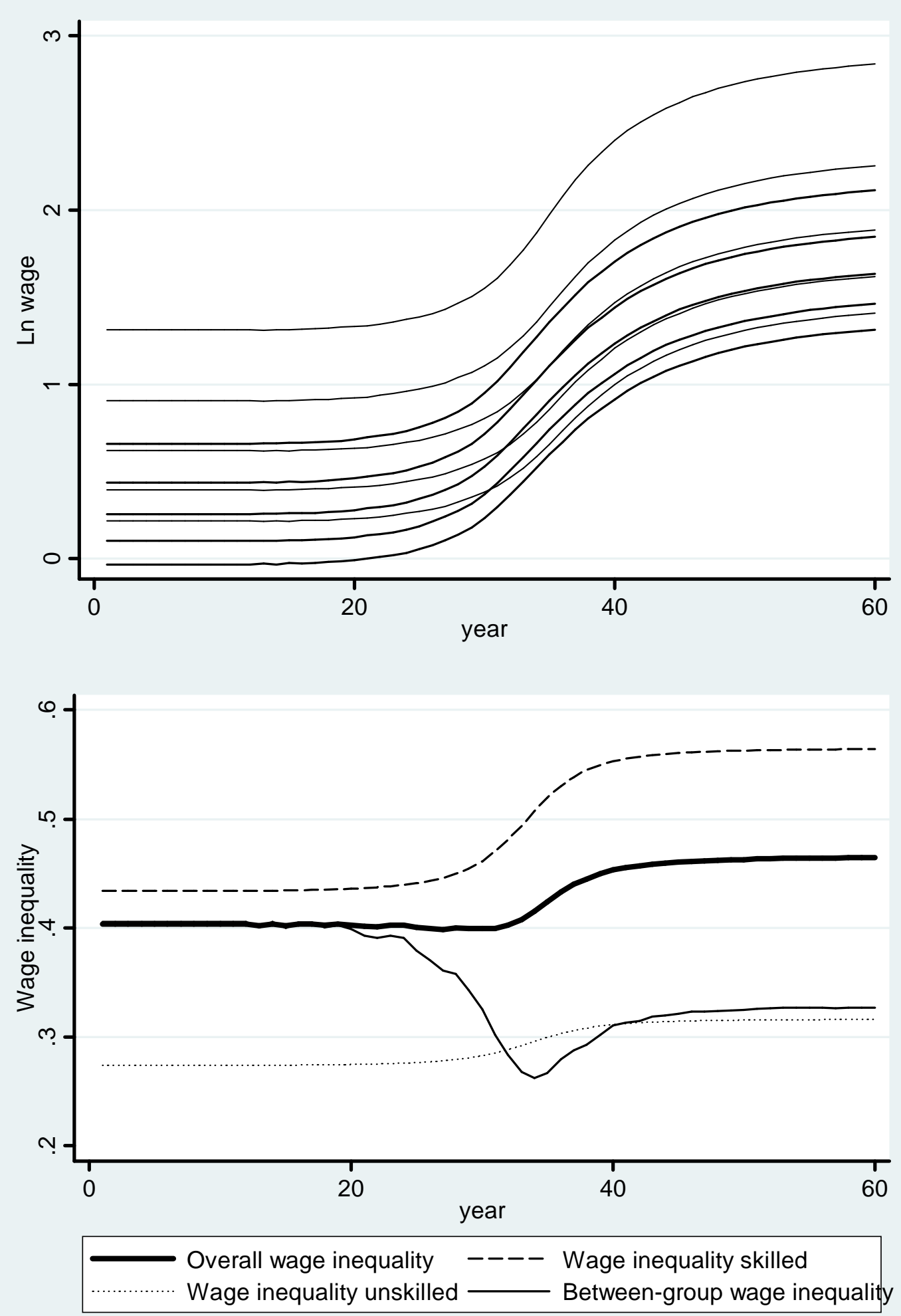


\section{Figure 15}

The case with differences in complementary skills when workers are not perfectly substitutable
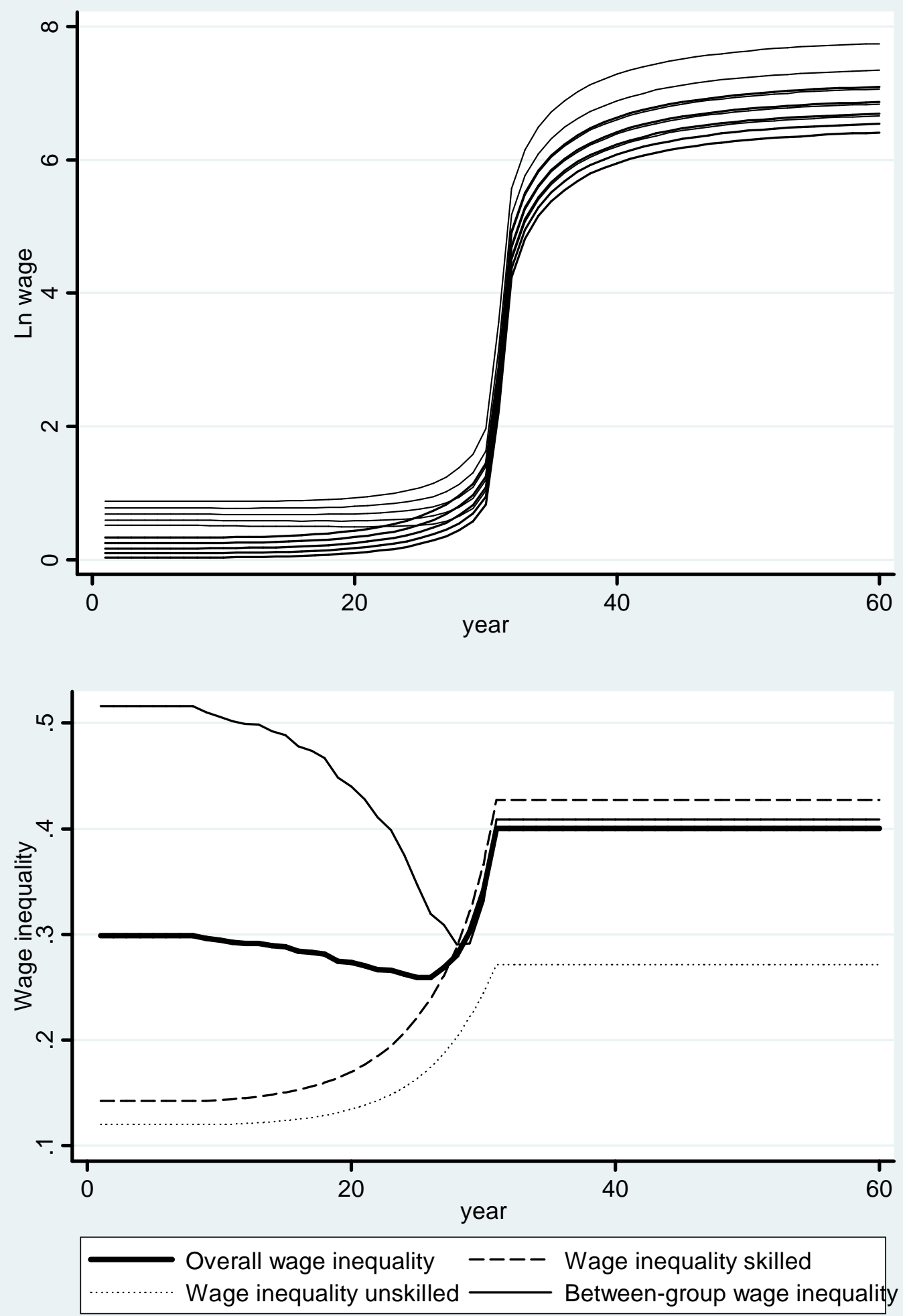


\section{Figure 16}

The case with fixed costs for using computer technology when workers are not perfectly substitutable
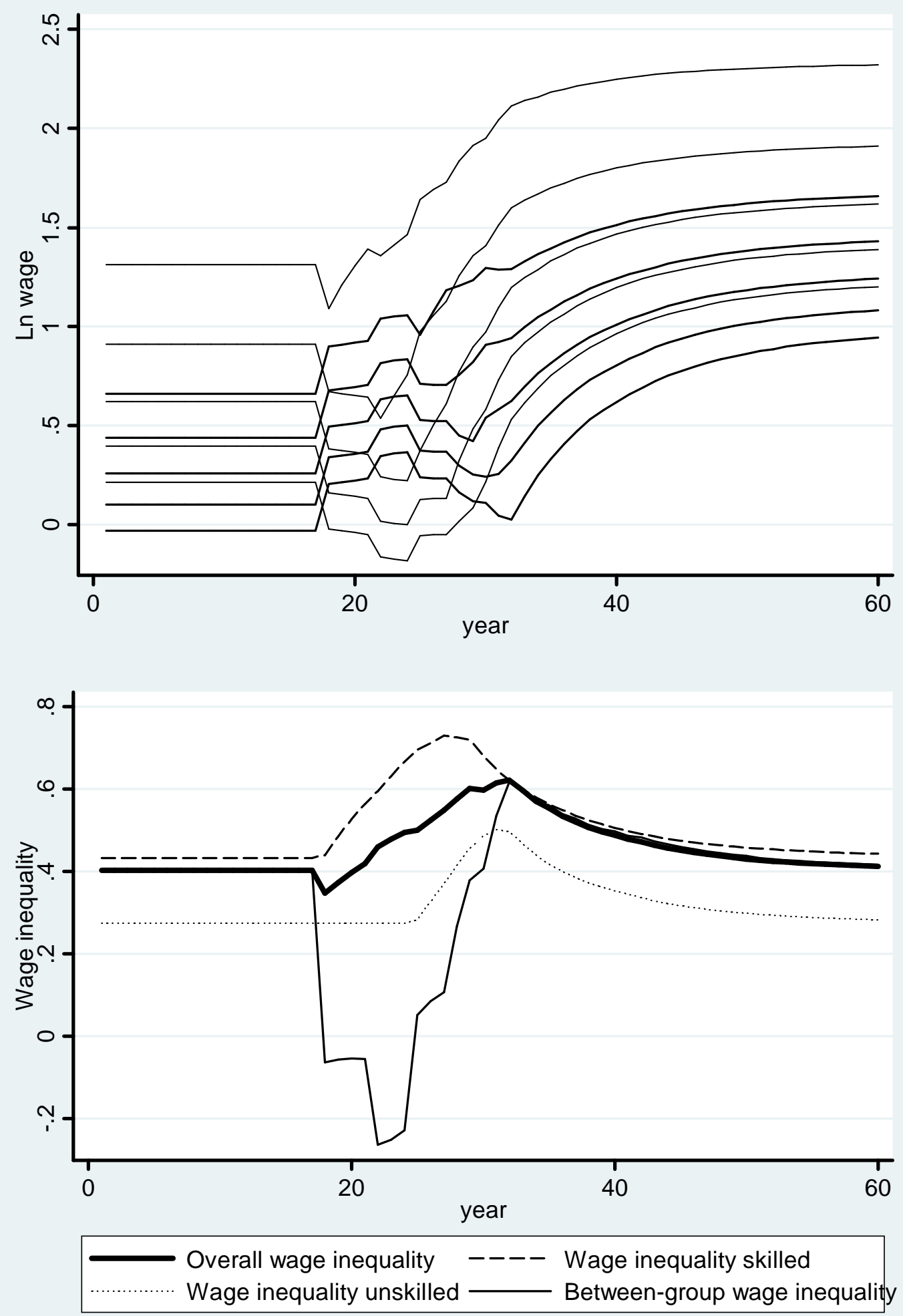
Figure 17

Age-wage profiles of computer use in Britain in 1997

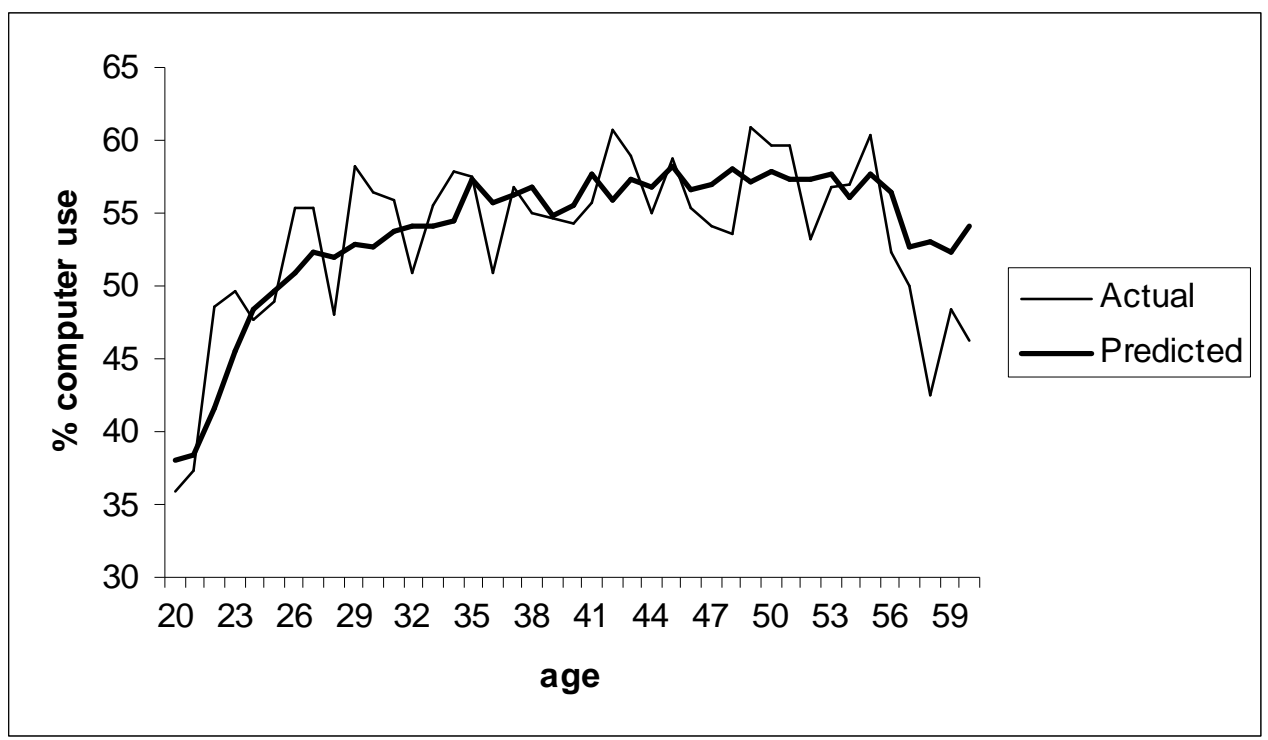

Note: The data are taken from the 1997 British Skills Survey 
Figure 18

Wages and computer use in Germany and the United States

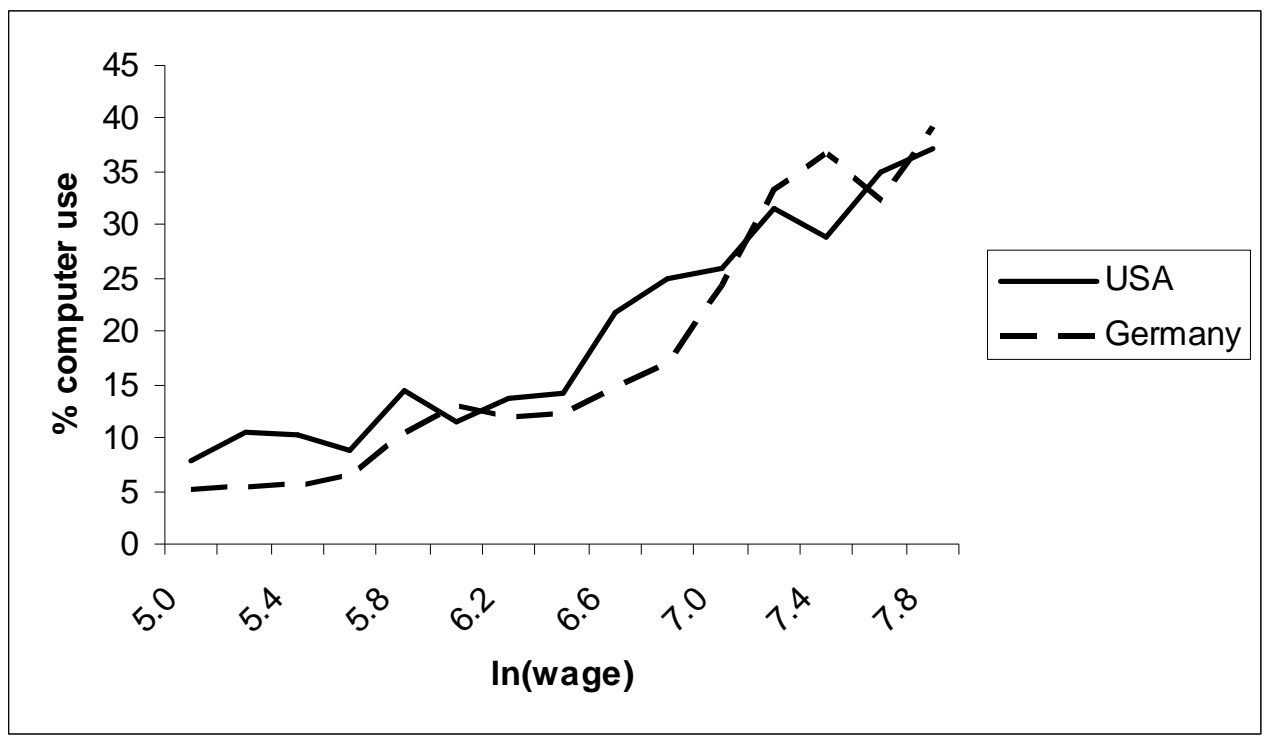




\section{Table 1}

Estimates for the elasticity of substitution and trends for the United States (dependent variable log relative wages (standard errors in brackets))

\begin{tabular}{|l|l|l|l|l|}
\hline & $(1)$ & $(2)$ & $(3)$ & $(4)$ \\
\cline { 2 - 5 } & $1963-1987$ & $1963-1987$ & $1963-2002$ & $1963-2002$ \\
\hline$-1 / \sigma$ & $\begin{array}{l}-0.730 \\
(0.085)^{*}\end{array}$ & $\begin{array}{l}-0.589 \\
(0.122)^{*}\end{array}$ & $\begin{array}{l}-0.639 \\
(0.047)^{*}\end{array}$ & $\begin{array}{l}-0.636 \\
(0.119)^{*}\end{array}$ \\
\hline Elasticity of substitution $(\sigma)$ & 1.37 & 1.70 & 1.56 & 1.57 \\
\hline Time trend $(t)$ & $\begin{array}{l}0.025 \\
(0.003)^{*}\end{array}$ & $\begin{array}{l}0.019 \\
(0.005)^{*}\end{array}$ & $\begin{array}{l}0.022 \\
(0.001)^{*}\end{array}$ & $\begin{array}{l}0.022 \\
(0.005)^{*}\end{array}$ \\
\hline $\begin{array}{l}\text { Additional trend from 1980 } \\
\text { onwards }\end{array}$ & No & $\begin{array}{l}0.006 \\
(0.004)\end{array}$ & No & $\begin{array}{l}0.000 \\
(0.003)\end{array}$ \\
\hline
\end{tabular}

Note: $*$ is significant at the 5 percent level. All data are taken from the March Supplements to the Current Population Surveys, 1964-2003. 
Table 2

Percentage of workers in age, educational level and gender categories using computer technology at work in Britain, Germany and the United States

\begin{tabular}{|l|l|l|l|l|l|l|}
\hline & \multicolumn{3}{l}{ Britain } & Germany & \multicolumn{2}{l|}{ United States } \\
\cline { 2 - 7 } & 1985 & 1997 & 1985 & 1997 & 1984 & 1997 \\
\hline All workers & 19.3 & 69.2 & 19.3 & 56.2 & 24.3 & 52.5 \\
\hline Age & & & & & & \\
20-29 & 21.2 & 67.8 & 18.4 & 50.8 & 24.8 & 47.8 \\
$30-39$ & 24.0 & 71.6 & 22.0 & 57.6 & 27.9 & 54.3 \\
$40-49$ & 13.7 & 71.9 & 19.3 & 58.3 & 23.2 & 55.5 \\
$50-60$ & 17.1 & 63.0 & 13.8 & 56.6 & 18.4 & 50.6 \\
\hline Educational level & & & & & & \\
< High school & 12.0 & 40.2 & 4.3 & 23.8 & 5.1 & 12.6 \\
High school & 28.2 & 55.1 & 18.4 & 50.5 & 19.2 & 36.9 \\
Some college & 31.5 & 75.1 & 25.6 & 76.9 & 30.6 & 53.2 \\
College or higher & 45.9 & 95.5 & 33.6 & 87.6 & 42.4 & 71.2 \\
\hline Gender & & & & & & \\
Men & 24.1 & 69.2 & 18.6 & 54.4 & 21.6 & 43.6 \\
Women & 14.9 & 69.1 & 21.0 & 60.5 & 29.6 & 55.6 \\
\hline
\end{tabular}

Note: Data about computer technology use in Germany refers to the Länder of the former West Germany only. For German data are taken from the German Qualification and Career Survey. Information about Britain stems from the British Social Attitudes Survey for 1985 and the Skills Survey of the Employed British Workforce for 1997. Data on computer use in the United States are based on the 1984 and 1997 October Supplements to the Current Population Surveys. 


\section{Table 3}

OLS regression estimates of the effects of computer technology use on pay in the United States, 1984-1997 (dependent variable: ln hourly wage (standard errors in brackets))

\begin{tabular}{|l|l|l|l|l|}
\hline & 1984 & 1989 & 1993 & 1997 \\
\hline Uses computer & $.145(.009)^{*}$ & $.153(.009)^{*}$ & $.150(.009)^{*}$ & $.144(.010)^{*}$ \\
technology & $.058(.002)^{*}$ & $.070(.002)^{*}$ & $.070(.002)^{*}$ & $.072(.002)^{*}$ \\
Years of education & $.026(.001)^{*}$ & $.025(.001)^{*}$ & $.027(.001)^{*}$ & $.032(.002)^{*}$ \\
Experience & $-.043(.003)^{*}$ & $-.039(.003)^{*}$ & $-.045(.003)^{*}$ & $-.059(.004)^{*}$ \\
Experience squared/100 & $-.090(.011)^{*}$ & $-.087(.011)^{*}$ & $-.066(.011)^{*}$ & $-.076(.012)^{*}$ \\
Black & $-.212(.010)^{*}$ & $-.150(.011)^{*}$ & $-.188(.010)^{*}$ & $-.160(.012)^{*}$ \\
Part-time job & $-.189(.013)^{*}$ & $-.197(.013)^{*}$ & $-.132(.013)^{*}$ & $-.173(.015)^{*}$ \\
Female & $.134(.012)^{*}$ & $.142(.012)^{*}$ & $.151(.012)^{*}$ & $.123(.013)^{*}$ \\
Married & $.244(.010)^{*}$ & $.224(.010)^{*}$ & $.238(.011)^{*}$ & $.201(.013)^{*}$ \\
Union member & & & & \\
\hline Occupational dummies & Yes & Yes & Yes & Yes \\
Industry dummies & Yes & Yes & Yes & Yes \\
Regional dummies & Yes & Yes & Yes & Yes \\
\hline Adjusted $\mathrm{R}^{2}$ & .409 & .412 & .417 & .381 \\
\hline
\end{tabular}

Note: * is significant at the 5 percent level. All data are taken from the October Supplements to the Current Population Survey in the relevant years. The regression equation also included dummies for living in a small or medium-sized area and female*married. 